\title{
Therapeutic progress and challenges for triple negative breast cancer: targeted therapy and immunotherapy
}

\author{
Ruoning Yang ${ }^{1,2 \dagger}$, Yueyi $\mathrm{Li}^{1 \dagger}$, Hang Wang ${ }^{1}$, Taolin Qin ${ }^{3}$, Xiaomeng Yin ${ }^{1}$ and Xuelei Ma ${ }^{1 *}$
}

\begin{abstract}
Triple negative breast cancer (TNBC) is a subtype of breast cancer, with estrogen receptor, human epidermal growth factor receptor 2 and progesterone receptor negative. TNBC is characterized by high heterogeneity, high rates of metastasis, poor prognosis, and lack of therapeutic targets. Now the treatment of TNBC is still based on surgery and chemotherapy, which is effective only in initial stage but almost useless in advanced stage. And due to the lack of hormone target, hormonal therapies have little beneficial effects. In recent years, signaling pathways and receptor-specific targets have been reported to be effective in TNBC patients under specific clinical conditions. Now targeted therapies have been approved for many other cancers and even other subtypes of breast cancer, but treatment options for TNBC are still limited. Most of TNBC patients showed no response, which may be related to the heterogeneity of TNBC, therefore more effective treatments and predictive biomarkers are needed. In the present review, we summarize potential treatment opinions for TNBC based on the dysregulated receptors and signaling pathways, which play a significant role in multiple stages of TNBC development. We also focus on the application of immunotherapy in TNBC, and summarize the preclinical and clinical trials of therapy for patients with TNBC. We hope to accelerate the research and development of new drugs for TNBC by understanding the relevant mechanisms, and to improve survival.
\end{abstract}

Keywords: Triple negative breast cancer, TNBC, Targeted therapy, Immune checkpoint inhibitors, Signaling pathways

\section{Introduction}

Breast cancer is the most commonly diagnosed cancer in 2020 (11.7\% of total cases) and the leading cause of cancer death among women [1]. Triple negative breast cancer (TNBC))is a subtype of breast cancer, which represents $24 \%$ of all types of breast cancers [2]. In 2000, the first-generation cDNA microarrays defined basal-like breast cancer as a subtype of breast cancer, which shows low expression level of estrogen receptor (ER) and associated genes, no expression of human epidermal growth factor receptor 2 (HER2) and strong expression of breast basal cell keratins 5/6 and 17 [3]. Then, in 2005, James

\footnotetext{
*Correspondence: drmaxuelei@gmail.com

${ }^{\dagger}$ Ruoning Yang and Yueyi Li contributed equally to thiswork.

${ }^{1}$ Department of Biotherapy, State Key Laboratory of Biotherapy,Cancer

Center, West China Hospital, 37 Guoxue Alley, Chengdu 610041, PR, China

Full list of author information is available at the end of the article
}

$D$ et al. defined a group of basal-like breast cancer with ER negative, HER2 negative and progesterone receptor (PR) negative as TNBC by immunohistochemical profiling [4]. In 2011, Lehmann et al. identified six TNBC subtypes, including 2 basal-like (BL1 and BL2), an immunomodulatory (IM), a mesenchymal (M), a mesenchymal stem-like (MSL), and a luminal androgen receptor (LAR) subtype [5].Compared with non-TNBC, TNBC occurs at younger age and shows higher histologic grade and more frequent lymph nodal metastases, meaning aggressive pathology [6]. And due to the lack of receptors, almost all TNBC is insensitive to hormone treatment or antiHER2 treatment [7]. At present, chemotherapy (anthracyclines and taxanes) is still the dominant treatment for patients with TNBC [5]. Although patients with TNBC have a high rate of clinical response to chemotherapy, they show poor prognosis and high risk of recurrence

\section{Springer}

(c) The Author(s) 2022. Open Access This article is licensed under a Creative Commons Attribution 4.0 International License, which permits use, sharing, adaptation, distribution and reproduction in any medium or format, as long as you give appropriate credit to the original author(s) and the source, provide a link to the Creative Commons licence, and indicate if changes were made. The images or other third party material in this article are included in the article's Creative Commons licence, unless indicated otherwise in a credit line to the material. If material is not included in the article's Creative Commons licence and your intended use is not permitted by statutory regulation or exceeds the permitted use, you will need to obtain permission directly from the copyright holder. To view a copy of this licence, visit http://creativecommons.org/licenses/by/4.0/. 
[8]. And once diagnosed as metastatic TNBC, adjuvant therapy is often ineffective and the median survival time after metastasis is only 13.3 months [8, 9]. Thus, in addition to the development of new applications of existing drugs, there is an urgent need for new drugs and therapies to improve the therapeutic effect of TNBC. With the development of precision therapy, many studies have demonstrated that the targeted therapy has promising value in TNBC. Many abnormal pathways in TNBC have been reported, like Phosphatidylinositol-3-kinase (PI3K)/ AKT/ mammalian target of rapamycin (mTOR), the Ras/ mitogen-activated protein kinase (MAPK) pathway, the epithelial-mesenchymal transition (EMT) and associated pathways, and so on. Besides, many mutations have been found in TNBC, like germline BRCA1 or BRCA2 mutations. These findings bring new hope for the treatment of TNBC. Besides, target therapy is found to improve the resistance to treatment which often occurs in advanced patients. In the present review, we summarize potential treatment opinions for TNBC based on the dysregulated receptors and signaling pathways, as well as the application of immunotherapy in TNBC, and list related preclinical and clinical trials to provide new ideas and directions for TNBC treatment. We list clinical trials of TNBC with and without results in Supplementary Table 1. And partial of clinical trials with results for patients with TNBC are shown in Table 1.

\section{Receptor tyrosine kinases and associated pathways Receptor tyrosine kinases (RTKs) family}

RTKs family is a kind of transmembrane enzyme-linked receptor on cell surface, composing of an extracellular ligand-binding region, a single transmembrane helix, a protein tyrosine kinase domain and juxta membrane regulatory regions [20]. There are 58 different kinds of receptors, such as epidermal growth factor receptor (EGFR), vascular endothelial growth factor receptor (VEGFR), insulin-like growth factor receptor (IGFR), fibroblast growth factor receptor (FGFR) and AXL [21]. RTKs binding to ligands to induce the dimerization of the receptors, which then activates the downstream PI3K/ AKT/mTOR pathway, RTK/Ras/MAPK pathway and janus kinase/signal transducer and activator of transcription protein family pathway $[20,22]$. The conduction processes are showed in Fig. 1. Mutations or disorders of different RTK can drive cancer progression, therefore, it is theoretical plausible to target these RTKs for cancer treatment [23-25]. Now more and more tyrosine kinase inhibitors (TKIs) and anti-TKI antibodies have received approvement from U.S. Food and Drug Administration (FDA) for applications in cancer treatment [20,22].

TKI is an important targeted drug in tumor therapy and have demonstrated excellent antitumor effects in some cancer. In TNBC patients, the effect of TKIs alone is unclear in the treatment, but it seems unlikely that treatment with tyrosine kinase inhibitors to patients with unselected TNBC would be effective as it is a monotherapy. It needs to be used in combination with other drugs to achieve the desired effect [26]. Lapatinib is the only anti-EGFR agent approved by the FDA for clinical use, and it is recommended to use in combination with chemotherapy or hormone therapy. It was shown to be effective even in trastuzumab-resistant tumors. However, until now the results were frustrating, and no other EGFR inhibitor has made it to clinical use in TNBC [27]. As a common targeted drug, TKIs are less likely to cause toxic effects of traditional chemotherapy such as cumulative bone marrow toxicity, yet it does have a different toxicity profile, as it mainly causes skin and gastrointestinal toxicities, including diarrhea and rashes [28].The biggest challenge for the application of TKIs in clinical practice is drug tolerance, which has been found to be correlated with the overexpressed ALX in resistant tumors [29, 30]. Over 50\% of patients with TNBC show overexpression in EGFR overall, indicating that anti-EGFR therapy is promising for TNBC patients with positive EGFR mutations [31]. But early phase clinical trials failed to consistently justify significant effectiveness of anti-EGFR antibody in TNBC patients [26]. Actually, the same result was showed when it combined with routine chemotherapy drug. A meta-analysis shows that cetuximab, the first FDA-approved EGFR-targeted antibody, combined with chemotherapy used in TNBC excelled significant superiority in progression free survival (PFS) over chemotherapy alone [32]. A phase II study compares the pathologic complete response rate, safety and toxicity of cetuximab combined with ixabepilone in TNBC patients (NCT01097642). A triple-combination therapy of ipatasertib, atezolizumab and paclitaxel as treatment for patients with locally advanced or metastatic TNBC is now undergoing phase III trial (NCT04177108). As previously mentioned, the phenomenon of drug resistance is possibly caused by the involvement of AXL in apoptotic cells clearance. Meanwhile AXL is highly expressed in TNBC, and such high expression is significantly associated with lymphovascular invasion, suggesting the potential of targeted-AXL drugs in combination with other targeted agents [33]. Bemcentinib (BGB324) is the first AXL inhibitor applicated in clinical practice [34]. Currently, a phase II trial of bemcentinib combined with pembrolizumab is conducted to examinate the anti-tumor activity and assess the safety of in TNBC patients (NCT03184558). In the future, the researchers should explore the anti-AXL drug in combination with TKIs in TNBC treatment. In conclusion, 
Table 1 Partial clinical trials of targeted agents involving patients with TNBC

\begin{tabular}{|c|c|c|c|c|c|c|c|}
\hline \multirow[t]{2}{*}{ Pathway } & \multirow[t]{2}{*}{ NCT } & \multirow[t]{2}{*}{ Phase } & \multicolumn{2}{|l|}{ Results } & \multicolumn{2}{|l|}{ Treatment } & \multirow[t]{2}{*}{ Reference } \\
\hline & & & Group 1 & Group 2 & Group 1 & Group 2 & \\
\hline $\begin{array}{l}\text { Combination } \\
\text { (Chemotherapy) }\end{array}$ & NCT02547987 & $\|$ & $\begin{array}{l}\text { pCR: } 45.7 \%(95 \% \mathrm{Cl} \\
36.9-54.7 \%)\end{array}$ & & $\begin{array}{l}\text { Docetaxel + Carbo- } \\
\text { platin }\end{array}$ & & [10] \\
\hline $\begin{array}{l}\text { Combination (CDK } \\
\text { inhibitor + Paclitaxel) }\end{array}$ & NCT02779855 & $|/| \mid$ & RR: $55 \%$ & & $\begin{array}{l}\text { Talimogene Laher- } \\
\text { parepvec+ Neoadju- } \\
\text { vant Chemotherapy } \\
\text { (doxorubicin/cyclo- } \\
\text { phosphamide) }\end{array}$ & & [11] \\
\hline $\begin{array}{l}\text { Selective Inhibitor of } \\
\text { Nuclear Export }\end{array}$ & NCT02402764 & $\|$ & $\begin{array}{l}\text { mPFS: } 0.92 \text { months } \\
\text { (95\%Cl: } 0.62-3.58) \\
\text { mOS: } 5.98 \text { months } \\
(95 \% \text { Cl: } 1.68-10.39)\end{array}$ & & Selinexor & & {$[12]$} \\
\hline $\begin{array}{l}\text { Combination (CSF-1 } \\
\text { inhibitor Chemo- } \\
\text { therapy) }\end{array}$ & NCT02435680 & $\|$ & $\begin{array}{l}\text { PFS: } 5.6 \text { months } \\
\text { (95\% Cl:4.5-8.7) }\end{array}$ & $\begin{array}{l}\text { PFS: } 5.5 \text { months } \\
\text { ( } 95 \% \text { Cl: } 3.5-7.5)\end{array}$ & $\begin{array}{l}\text { MCS110+ Chemo- } \\
\text { therapy (carbopl- } \\
\text { atin + gemcitabine) }\end{array}$ & $\begin{array}{l}\text { Chemotherapy } \\
\text { (carboplatin + gem- } \\
\text { citabine) }\end{array}$ & \\
\hline Chemotherapy & NCT02413320 & $\|$ & pCR: $54.2 \%$ & pCR: $53.8 \%$ & $\begin{array}{l}\text { Carboplatin + Pacli- } \\
\text { taxel + Doxoru- } \\
\text { bicin + Cyclophos- } \\
\text { phamide }\end{array}$ & $\begin{array}{l}\text { Carboplatin + Doc- } \\
\text { etaxel }\end{array}$ & [13] \\
\hline $\begin{array}{l}\text { Combination (AKT } \\
\text { inhibitor + Paclitaxel) }\end{array}$ & NCT02301988 & $\|$ & $\begin{array}{l}\text { pCR: } 17.1 \%(95 \% \mathrm{Cl} \text {, } \\
9.82 \%-27.25 \%)\end{array}$ & $\begin{array}{l}\text { PCR: } 13.3 \%(95 \% \mathrm{Cl} \text {, } \\
6.58 \%-22.86 \%)\end{array}$ & $\begin{array}{l}\text { Ipatasertib + Pacli- } \\
\text { taxel }\end{array}$ & Placebo + Paclitaxel & [14] \\
\hline $\begin{array}{l}\text { Combination (AKT } \\
\text { inhibitor + Paclitaxel) }\end{array}$ & NCT02423603 & $\|$ & mPFS: 5.9 months & mPFS: 4.2 months & Paclitaxel + AZD5363 & Paclitaxel + Placebo & [15] \\
\hline $\begin{array}{l}\text { Combination (AKT } \\
\text { inhibitor + Paclitaxel) }\end{array}$ & NCT03337724 & III & $\begin{array}{l}\text { mPFS: } 9.3 \text { months } \\
(95 \% \mathrm{Cl}, 8.0-11.0)\end{array}$ & $\begin{array}{l}\text { mPFS: } 9.3 \text { months } \\
(95 \% \mathrm{Cl}, 7.2-12.2)\end{array}$ & $\begin{array}{l}\text { Ipatasertib + Pacli- } \\
\text { taxel }\end{array}$ & Placebo + Paclitaxel & [16] \\
\hline$A D C$ & NCT03106077 & $\|$ & Stable Disease: 50\% & & $\begin{array}{l}\text { Mirvetuximab } \\
\text { Soravtansine }\end{array}$ & & \\
\hline$A D C$ & NCT02984683 & $\|$ & TEAEs: 100\% & TEAEs: $100 \%$ & $\begin{array}{l}\text { SAR566658 (90 mg/ } \\
m \wedge 2)\end{array}$ & $\begin{array}{l}\text { SAR566658 (120 mg/ } \\
\left.\mathrm{m} \wedge^{\wedge} 2\right)\end{array}$ & \\
\hline$A D C$ & NCT02078752 & । & $\begin{array}{l}\text { ORR: } 8.3(95 \% \mathrm{Cl} \\
0.2-38.5)\end{array}$ & & PF-06647263 & & [17] \\
\hline$A D C$ & NCT01997333 & $\|$ & $\begin{array}{l}\text { PFS: } 2.9 \text { months } \\
(95 \% \text { Cl: } 2.8-3.5)\end{array}$ & $\begin{array}{l}\text { PFS: } 2.8 \text { months } \\
\text { (95\% Cl: } 1.6-3.2 \text { ) }\end{array}$ & CDX-011 & Capecitabine & \\
\hline$A D C$ & NCT01631552 & $|/| \mid$ & $\begin{array}{l}\text { mPFS:5.5 months } \\
(95 \% \mathrm{Cl}, 4.1-6.3)\end{array}$ & & SG & & [18] \\
\hline$A D C$ & NCT02574455 & III & $\begin{array}{l}\text { mPFS: } 5.6 \text { months } \\
(95 \% \mathrm{Cl}, 4.3-6.3)\end{array}$ & $\begin{array}{l}\text { mPFS: } 1.7 \text { months } \\
(95 \% \mathrm{Cl}, 1.5-2.6)\end{array}$ & SG & $\begin{array}{l}\text { Chemotherapy } \\
\text { (eribulin/capecit- } \\
\text { abine/gemcitabine/ } \\
\text { vinorelbine) }\end{array}$ & [19] \\
\hline
\end{tabular}

Clinicaltrials.gov, accessed on November 1, 2021

it is regrettable that there are no drugs targeting RTKs family approved into clinical application for patients with TNBC.

\section{$\mathrm{PISK} / \mathrm{AKT} / \mathrm{mTOR}$ signaling pathways}

The PI3K/AKT/mTOR pathway is important in chemoresistance and survival of TNBC, involving in cell metabolism, proliferation, migration and survival [35]. PI3K is firstly activated by RTKs, and then phosphorylates 4,5-phosphoinositide (PIP2) into 3,4,5-phosphoinositide (PIP3), which binds to AKT, and followed by phosphorylation of threonine and serine to completely activate AKT [36-38]. In addition, there are other regulatory factors in this cellular pathway. Phosphatase and tension homolog (PTEN), a negative regulatory phosphatase of PI3K signaling, can suppress tumor by converting PIP3 to PIP2 [39]. Through tuberous sclerosis complex $1 / 2$, AKT activates the downstream mTOR, which exists in mTOR complex (mTORC) 1 and mTORC2 respectively [35, 40, 41]. MTORC 1 is linked to lipid synthesis and decomposition, and also regulates growth-stimulatory effects of mTOR [42]. By contrast, mTORC2 can further activate AKT, be involved in cell migration and regulate actin cytoskeleton $[43,44]$. Many studies reported that abnormality of the PI3K/PTEN/AKT pathway is presented in more than $25 \%$ of TNBC patients, including 


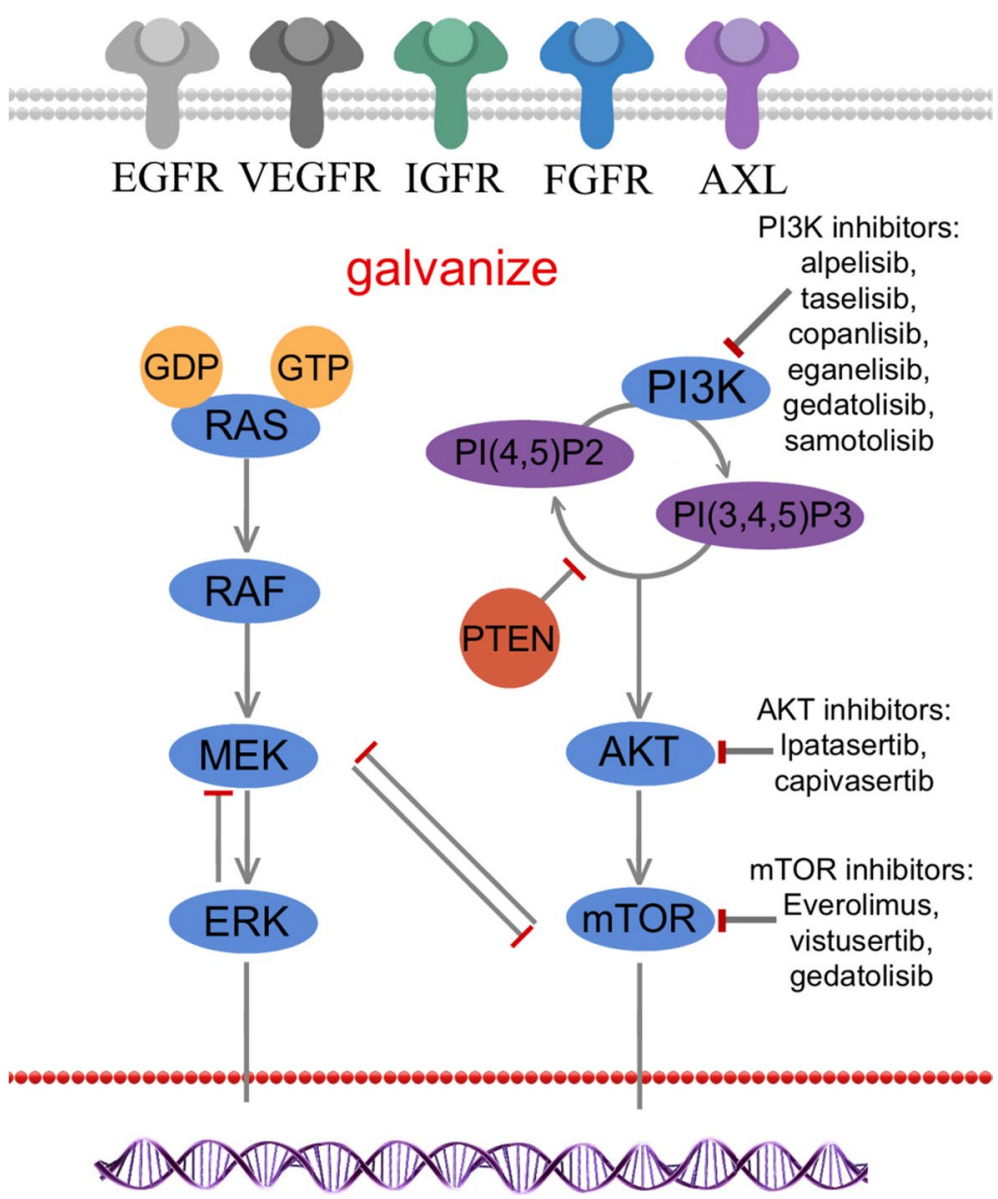

Fig. 1 Receptor tyrosine kinases and associated pathways in TNBC. RTKs bind to extracellular ligands, then activated RTKs then activates downstream PI3KAKT/ mTOR and Ras/MAPK pathway signaling pathways. After Ras family (N-Ras, M-Ras, H-Ras and K-Ras) is activated, downstream Raf, MEK and ERK in turn transfers the signals released from Ras to the nucleus, and finally drives tumor cell proliferation and survival. PI3K is firstly activated by RTKs, and then phosphorylates PIP2 into PIP3, which binds to AKT, and followed by phosphorylation of threonine. And AKT and mTOR are completely activated in turn. PTEN is a negative regulatory phosphatase of PI3K signaling, which can suppress tumor by converting PIP3 to PIP2

PIK3CA-activating mutations, PTEN loss, AKT1 activating mutations and mTOR activation [45-48]. Hyperactivation of AKT and mTOR may lead to an unfavorable prognosis of TNBC patients, suggesting that targeting some factors in this pathway is a promising strategy for TNBC treatment [49-51].

Everolimus is a mTORC1 inhibitor, which was approved by the FDA for postmenopausal patients with hormone receptor $(\mathrm{HR})+/$ HER2- advanced breast cancer [52]. The efficacy of everolimus has been confirmed by many studies [53-55]. In a randomized trial, researchers exanimated the safety of the everolimus in patients with hormone-receptor-positive advanced breast cancer. The most common grade 3 or 4 adverse events (AEs) were stomatitis, anemia, dyspnea, hyperglycemia, fatigue, and pneumonitis [52]. Further finding is that the clinical benefit of mTOR inhibitor alone is far from satisfactory, and obviously the combination therapy renders more clinical benefit [56]. Everolimus-carboplatin was reported to be efficacious in metastatic TNBC [57]. Compared with neoadjuvant alone, the combination of everolimus plus cisplatin after neoadjuvant shows lower residual cancer burden [58]. PI3K inhibition would diminish nucleotide pools required for DNA synthesis and S-phase progression, resulting in sensitization to PARP inhibitors in BRCA-proficient TNBC [59]. Based on this, a new, non-chemotherapy treatment option for TNBC with wild-type BRCA might originate from the combination of a PI3K inhibitor and PARP inhibitor. The evaluation over efficacy of gedatolisib, a PI3K and mTOR inhibitor, in combination with talazoparib (PARP inhibitor) in TNBC or BRCA1/2 positive breast cancer with HER2 negative was conducted in a phase II clinical trial. (NCT03911973). And the AEs of gedatolisib have been concerned in other solid tumors. In a multi-arm 
clinical trial of gedatolisib and irinotecan in advanced sloid cancers, the most common gedatolisib-related AEs were nausea (61.4\%), diarrhea (52.3\%), vomiting (40.9\%), mucosal inflammation/stomatitis (34.1\%), decreased appetite (31.8\%) and fatigue (29.5\%), mostly of grade 1 or 2 [60]. However, there are no studies specifically focusing on AEs of PI3K/AKT/mTOR signaling pathways in patients with TNBC. To sum up, more trials are needed to explore the combinations of PI3K/ AKT/mTOR signaling pathways in the future, in addition, how to exert the role of negative regulatory factors in the pathway to achieve anti-tumor effects is also a potential research direction.

\section{The Ras/ MAPK pathway}

Ras family, small GTPases, consisting of N-Ras, M-Ras, $\mathrm{H}$-Ras and K-Ras, can be firstly activated by external stimuli like ligand activation of RTK [61]. Then downstream Raf, MAPK kinase 1 (MEK) and extracellular signal-regulated kinases (ERK) in turn transfers the signals released from Ras to the nucleus, and finally drives cell proliferation and survival [62]. Negative regulation of the pathway is accomplished through the action of DUSP family phosphatases on ERK, the hydrolysis of Ras-associated GTP by NF1, and the negative feedback actions of ERK on both MEK and Raf signaling complexes, among others. The copy number alterations of RAS/MAPK signaling pathways in TNBC was found to be greater than other subtypes of breast cancer, suggesting the connection the pathway activation and $\mathrm{TNBC}^{5}$. Excessive positive regulation and lack of negative regulation can both lead to abnormal copy number of the pathway [63]. Inhibitors of MEK is a significant node in the Ras/MAPK pathway, which can inhibit specifically inhibit proliferation of TNBC cell lines [61]. Selumetinib (AZD6244; ARRY-142886), a MEK inhibitor, has shown the ability to inhibit the process of EMT and restrain lung metastasis in animal models of TNBC [64]. A clinical trial in advanced cancer patients with the CI-1040 (an oral MEK inhibitor) shows the usual toxicities of CI-1040 were mild or moderate, like diarrhea, nausea, asthenia, and vomiting [65].Compared with solo therapy, combination therapy with MEK inhibitors seems to be more promising. The combination of CH5126766(RAF/MEK inhibitor) and eribulin was tested to potently inhibit cell growth in TNBC and to suppress the expression of programmed cell death-ligand 1 (PD-L1) [66]. A phase I/II study of AZD2014 (vistusertib, mTOR inhibitors) administered with selumetinib is carrying out a dose-escalation experiment in TNBC patients (NCT02583542).

\section{Cyclin-dependent kinases (CDKs) 4/6}

The mitotic cell cycle is an important process of cell proliferation, depending heavily on continuous activation of several CDKs complexes, while dysregulation of cellular proliferation is considered to be omnipresent in all cancers [67]. Cyclin D, a member of the cyclin family, forms a complex with CDK4/6 kinases to participate in cell cycle progression from the first growth (G1) to the DNA synthesis (S) phase [68]. Cyclin D-CDK4/6 complex gets activated when it gets into the nucleus, and then phosphorylates retinoblastoma protein $(\mathrm{Rb})$. Phosphorylated $\mathrm{Rb}$ can inhibit transcription factors like E2F, and initiates the cell into $S$ phase and drives DNA replication [69]. The initial phosphorylation of Rb depends on cyclin D-CDK $4 / 6$ complex and the hyperphosphorylation of $\mathrm{Rb}$ often leads to the loss of its tumor suppressive function. Therefore, CDK4/6 inhibitors can inhibit Rb phosphorylation to prevent the proliferation of tumor cells. The process of CDK 4/6 signaling pathways mediated cell cycle progression in TNBC is showed in Fig. 2. In addition, CDK5 is an atypical member of the cyclin-dependent kinase family, and its aberrant expression is also related to cell proliferation, DNA damage response, apoptosis, migration and angiogenesis in cancer. Some studies indicated that new post-translational modifications (PTMs) of CDK5 act as molecular switches to control the kinase activity of CDK5 in the cell [11].

Till now, FDA have approved three CDK inhibitors for patients with ER +/HER2 + breast cancer, including palbociclib, ribociclib and abemaciclib [70-72]. Regretfully, no CDK4/6 inhibitor is approved for TNBC and its efficacy in TNBC needs further examination. Genetic analysis of TNBC shows that $20 \%$ of TNBC patients have Rb1 loss, 9\% of them show cyclin E1 amplification. Lower RB1 expression is considered to be related to the insensitivity to the CDK4/6 inhibitors [45]. Besides, preclinical trials have proven that TNBC was extremely sensitive to CDK4/6 inhibitors in vitro and vivo, especially for luminal androgen receptor (LAR) subtype [73, 74], suggesting that there may be yet-undiscovered mechanisms. There are many ongoing studies on CDK4/6 inhibitors in TNBC. Now, a phase II clinical trial is evaluting the efficacy and safety of aemaciclib for patients with Rb + TNBC. (NCT03130439). Besides, CDKs link cell proliferation with other signaling pathways, making the combination therapy also worth exploring. For example, CDK $4 / 6$ can regulate $T$ cells to enhance immune function and inhibit the cytotoxicity of chemotherapy [67]. What's more, a phase I trial confirmed that palbociclib combined with paclitaxel is safe and free of additive toxicity for patients with $\mathrm{Rb}+$ breast cancer (NCT01320592). And the most common palbociclib-related $\mathrm{AE}$ in this trial was neutropenia, which was also the most common grade $3 / 4$ 


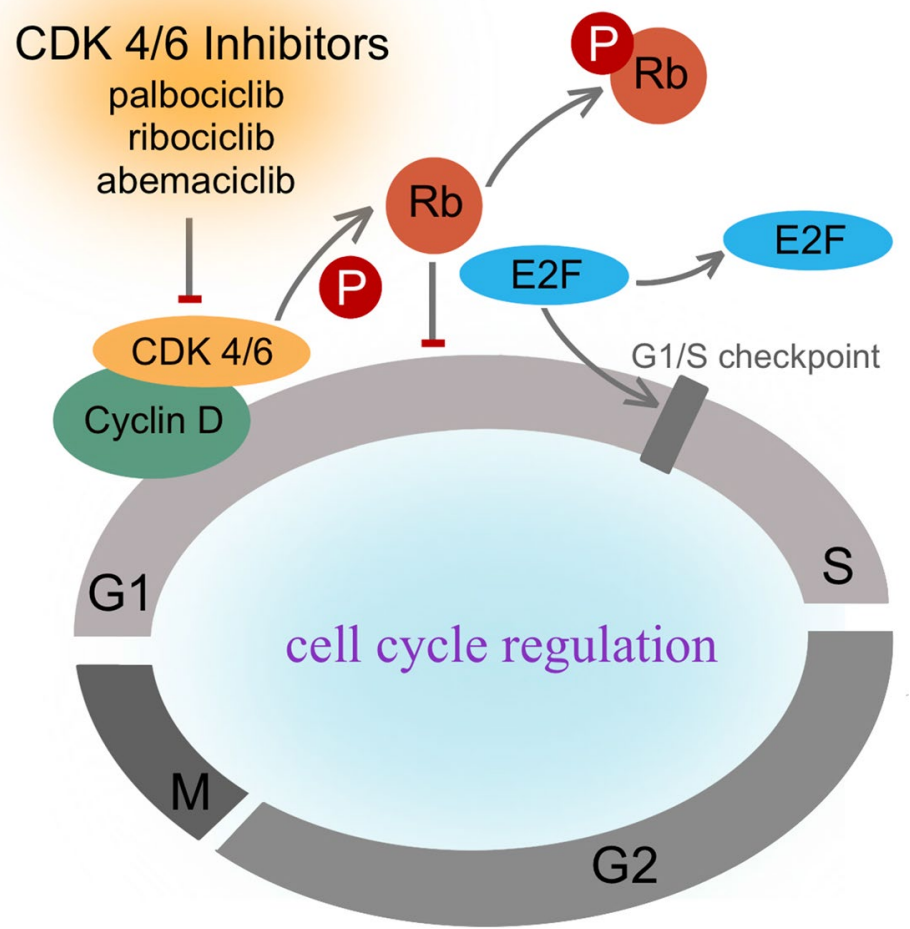

Fig. 2 Cyclin-Dependent Kinases 4/6 signaling pathways mediated cell cycle progression in TNBC. CDK 4/6—cyclin D complex gets into the nucleus, and then phosphorylates Rb. Phosphorylated Rb inhibits E2F, and initiates the cell into S phase and drives DNA replication. CDK4/6 inhibitors can inhibit Rb phosphorylation to prevent the proliferation of tumor cells

event, and other AEs may have relations with Paclitaxel therapy [11].Trilaciclib, a CDK 4/6 inhibitor, is in a clinical trial to exam its safety and efficacy when administered prior to chemotherapy in patients receiving first- or second-line treatment for locally advanced unresectable or metastatic TNBC (NCT04799249). And the expression of $\mathrm{Rb}$ was found to be highly related to androgen receptor (AR) expression in TNBC patients [75]. Targeting AR in TNBC has shown promising result and the combination of CDK 4/6 inhibitors and AR antagonists is also beneficial [75].

\section{Notching signaling}

The highly conserved Notch signaling is involved in angiogenesis, tumor growth, invasion and metastasis, even leading to the poor prognosis, resistance to treatments, and relapse of TNBC [76, 77]. Notch receptors on the surface of one cell bind to ligands of a neighboring cell, thus activate Notching pathways. As a single transmembrane protein, Notch ligand is composed of two parts: a typical extracellular DSL domain mediating receptor binding and multiple EGF-like repeats. Till now, 5 Notch ligands, Delta-like (Dll) 1, 3, 4, and Jagged (JAG) 1,2 , respectively and 4 Notch transmembrane receptors, Notch 1-4, have been found [78]. The Notch ligand-receptor complex is hydrolyzed by the ADAM17/ TACE metalloprotease and $\gamma$-secretase in turn, releasing the intracellular domain of Notch into the nucleus. Then the downstream gene transcription is activated, including cell-cycle regulators, transcription factors, and regulators of angiogenesis and apoptosis [78-80]. In addition, many other signaling pathway may affect the Notch signaling pathway, for instance, VEGFR3 V ER and HEY pathways [81]. Studies have found that Notch signaling pathway is overactivated in TNBC [76, 82]. Thus, targeting Notch signaling may be a promising treatment strategy. Although no FDA-approved therapy has existed for the Notch signaling pathway so far, there are still many studies exploring how to suppress Notch signaling at different levels of the cascade, among which the most promising is aspartyl protease inhibitors or $\gamma$-secretase inhibitors (GSIs), and several GSIs are already in clinical trials. For instance, as a powerful and selective small molecule GSIs, RO4929097 was found to be well-tolerated when given in intermittent or daily dosing [83]. The phase II clinical trial about RO4929097 in treating patients with advanced, metastatic, or recurrent TNBC has ended (NCT01151449). However, the GSIs are prone to AEs 
like diarrhea, affecting the digestive, circulation, hematological and other systems due to poor bioavailability and off-target side effects [84]. Dose-limiting intestinal toxicity is another disadvantage, which is also the main restriction of its clinical application [85]. To reduce the drug tocicity, intermittent administration has been proposed, but whether this affects the drug effect remains to be unclear [86]. In addition, great tolerance was observed in a clinical trial of an oral selective RO4929097 in combination with neoadjuvant chemotherapy in TNBC (NCT01238133), indicating that GSIs are effective in combination therapies [83]. CB-103 is a novel synthetic modulator of the Notch pathway, which seems to be more suitable for clinical application as it has no serious side effects or cytotoxicity compared with RO4929097. It is currently in clinical development. A phase I/II, dose escalation study investigates the safety, tolerability and preliminary efficacy of CB-103 in adult patients with advanced or metastatic solid tumors and hematological malignancies in "Recruiting" stage (NCT03422679).

\section{Poly-(ADP)-Ribose polymerase (PARPi)}

Breaks in DNA double-strand is a common DNA damage associated with tumorigenesis and BRCA 1 and BRCA 2 can repair the breaks in normal cell $[87,88]$. More than $15 \%$ patients with TNBC have BRCA 1 or 2 mutations, and patients with TNBC and BRCA2 mutation have similarities in clinical and pathological feature [89, 90]. There is evidence that PARP, a DNA repair enzyme, can promote the repair of single strand DNA breaks, which is a crucial way to repair when BRCA mutations occur. The disruption of PARP can lead to delayed repair and increased sensitivity to agents that induce base alkylation or DNA strand breaks [91]. This process is showed in Fig. 3. PARP inhibitors (PARPis) can suppress DNA repair through either poly-ADP ribosylation or the homologous

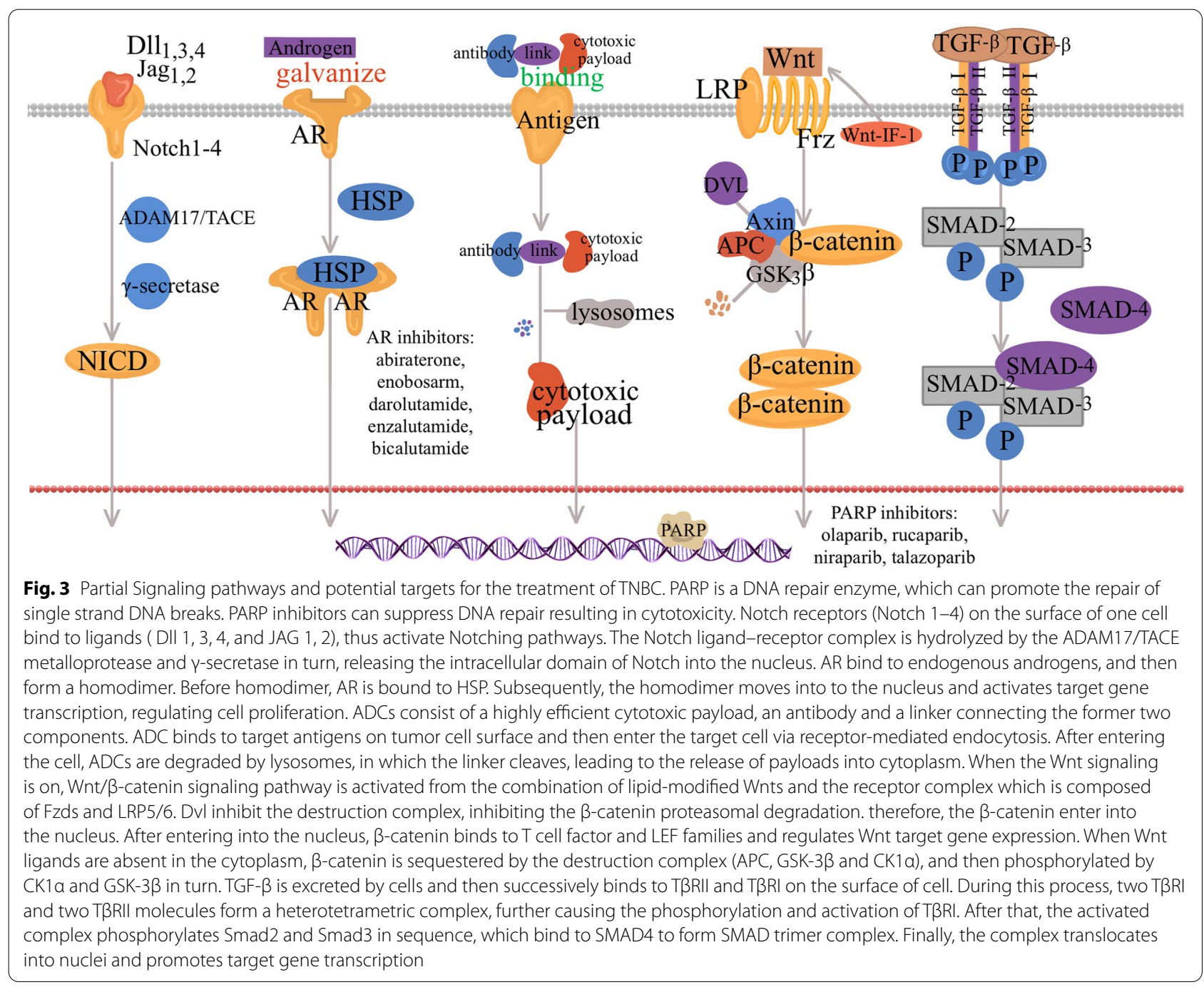


recombination pathway, resulting in cytotoxicity, which makes great progress in TNBC patients with BRCA $1 / 2$ mutations [92]. There are so far four common PARPis that have been developed, including olaparib, rucaparib, niraparib, and talazoparib, respectively [93]. In 2018, FDA approved olaparib and talazoparib for breast cancer with BRCA 1/2 mutations and HER2 negative [94]. The benefit of single agent olaparib in metastatic breast cancer patients with BRCA $1 / 2$ mutations has been tested in a phase III study (NCT02000622). In this trial, patients receiving olaparib monotherapy showed a 2.8-monthslonger median PFS (mPFS) and a $42 \%$-lower-risk of disease progression or death than receiving chemotherapy [95]. In the EMBRACA phase III trial that evaluated breast cancer patients with HER2 negative and germline BRCA1/2 mutations (NCT01945775), patients with talazoparib showed statistically overall improvements and significant delay in time to definitive clinically meaningful deterioration compared with those received chemotherapy (PFS: 8.6 vs. 5.6 months; hazard ratio $=0.54$ ) [96]. The remaining two PARPis, rucaparib and niraparib, are still in clinical trials. However, acquired resistance to PARPis in TNBC patients is an evitable problem and limits its use in clinical application [93]. To solve this, further molecular and clinical studies should be conducted to reveal the mechanisms of PARPi-resistance. Several researchers have proposed combination therapy with PARPis to overcome the resistance, which shows promising clinical prospects. For example, PARPis show better therapeutic effects when used in combination with platinum [97]. A phase II/III trial evaluates the safety and efficacy of the combination of platinum and olaparib in patients with TNBC (NCT03150576). A phase I/II study tests the safety and efficacy in TNBC patients with niraparib and pembrolizumab (NCT02657889) [98]. At present, except for the researches on combination therapy, researchers also have also focused on the clinical benefit of PARPis in TNBC patients without BRCA $1 / 2$ mutations. In addition, PARPi resistance is still the main problem limiting the clinic application of PARPis. Further molecular and clinical studies should be conducted to reveal the mechanisms of PARPi-resistance.

\section{Epithelial-to-mesenchymal transition and associated pathways Wnt/ $\beta$-Catenin signaling pathway}

As the canonical Wnt signaling, Wnt/ $\beta$-catenin signaling pathway is a highly conserved signaling pathway, associated with the progression of various tumors [99]. The upregulation of the Wnt/ $\beta$-catenin signaling pathway in patients with TNBC is found to have connections with the process of tumor proliferation, metastasis and the resistance to anticancer agents [100]. When Wnt ligands are absent in the cytoplasm, $\beta$-catenin is sequestered by the destruction complex (composing of adenomatous polyposis coli (APC), Axin, glycogen synthase kinase $3 \beta$ $($ GSK- $3 \beta)$ and casein kinase $1 \alpha(\mathrm{CK} 1 \alpha))$, and then phosphorylated by CK $1 \alpha$ and GSK-3 $\beta$ in turn [101-104]. Cullin1 and F-box protein $\beta$-TrCP can promote the ubiquitination of the destruction complex, leading to the degradation of $\beta$-catenin and the transcriptional repression of Wnt target genes [104].

When the destruction complex is inhibited by Dishevelled ( $\mathrm{Dvl}$ ), the $\beta$-catenin proteasomal degradation is disrupted, therefore, the $\beta$-catenin enter into the nucleus [105]. After entering into the nucleus, $\beta$-catenin binds to $\mathrm{T}$ cell factor and LEF families and regulates Wnt target gene expression [106].When the Wnt signaling is on, Wnt/ $\beta$-catenin signaling pathway is activated from the combination of lipid-modified Wnts and the receptor complex which is composed of Frizzleds (Fzds) and low-density lipoprotein receptor-related protein $5 / 6$ (LRP5/6). This process is showed in Fig. 3. So far, Fzd7 and LRP6 have been found to be upregulated in TNBC, thus, preventing Wnts from binding to the receptors can be beneficial to targeted therapy for TNBC [107-109]. For example, endogenous inhibitors like Wnt inhibitory factor 1 (WIF-1) can interact with Wnts to directly inhibit the pathway [110]. To our delight, deregulation of Wnt/ $\beta$-catenin signaling is found to be crucial in the development of the resistance to anti-cancer agents [99]. A series of agents for Wnt signaling pathway in TNBC have been developed through the past couple of decades, such as inhibition of Fzds or Dvl, inhibition or degradation of $\beta$-catenin and so on. Besides, it has been proved that targeting Wnt pathways can improve the resistance to carboplatin, thereby the combination of Wnt inhibitors and carboplatin can be an option in treatment of TNBC [111]. However, there are no available Wnt-targeted inhibitors applicated in clinical practice so far.

\section{TGF- $\beta$ /Smad signaling pathway}

TGF- $\beta$ signaling pathway plays a biphasic part in tumor progression, where TGF- $\beta$ serves as a tumor suppressor at the early stage and a tumor promoter at advanced stages [112]. There are three TGF- $\beta$ subtypes TGF- $\beta 1$, TGF- $\beta 2$, and TGF- $\beta 3$. As a secreted polypeptide, TGF- $\beta$ is excreted by cells and then successively binds to TGF- $\beta$ receptors on the surface of cells [113], including TGF- $\beta$ receptor type II (T $\beta R I I)$ and I (T $\beta R I)$. During this process, two T $\beta R I$ and two T $\beta R I I$ molecules form a heterotetrametric complex, further causing the phosphorylation and activation of T $\beta R I$ [114]. After that, the activated complex phosphorylates Smad2 and Smad3 in sequence, which bind to SMAD4 to form SMAD trimer complex. Finally, the complex translocates into nuclei and 
promotes target gene transcription $[115,116]$. When this pathway is overactivated, for instance, the overexpression of Smad-2 or Smad-3, the EMT can be induced inappropriately, mediating cancer metastasis $[117,118]$. This process is illustrated in Fig. 3. Compared with non-TNBC cells, the level of TGF- $\beta 1 \mathrm{mRNA}$, cell invasiveness and protein expression were evaluated to be higher in TNBC cells, which may have connections with the invasion and migration of TNBC [119]. Consequently, the motility and tumorigenicity of TNBC cells can be suppressed by the inhibition of TGF- $\beta /$ Smad signaling pathway. In an in-vitro cell model, zerumbone is found to induce the phosphorylation of Smad3, thereby suppressing the tumorigenicity of TNBC cells [119]. Another drug, LY2109761, a dual TGF- $\beta$ receptor I/II inhibitor, suppresses the TNBC cell migration and prevents the occurrence of metastasis $[119,120]$. Moreover, metformin is confirmed to block endogenous activation of Smad2 and Smad3 to inhibit the TGF- $\beta /$ Smad signaling pathway. Either metformin alone or combining with LY2197299 (galunisertib), a selective TGF- $\beta$ receptor I-kinase inhibitor, can attenuate TGF- $\beta$-induced proliferation [121, 122]. This discovery may provide a new option for TNBC patients clinically. Additionally, studies on TNBC cells suggest cancer stem-like cells (CSC) promote the process of chemotherapy-resistance and recurrence [123], and targeting TGF- $\beta$ signaling pathways can decrease the CSCs population in TNBC patients receiving chemotherapy [114]. For instance, LY2197299 has been demonstrated to inhibit the development of CSCs, suggesting the combination of chemotherapy and TGF- $\beta$-targeted agents as a potentially therapeutic option in TNBC [123]. Besides, a phase I trial is studying the best dose and side effects of M7824, an anti-PD-L1/TGF- $\beta$ antibody, when given together with eribulin mesylatein in patients with metastatic TNBC (NCT03579472). For future investigations, whether TGF- $\beta$ inhibitors in conjunction with conventional treatment can improve the curative effect remains to be determined. Whether assessing CSC population is needed to guide treatment also needs further discussion.

\section{Androgen receptors}

It has been indicated that AR is expressed in about $35 \%$ of TNBC and plays an important role as a potential therapeutic target [124]. According to gene expression profiles, TNBC with AR signaling is called a LAR subtype [5]. AR is a member of the steroid hormone receptor family, which is usually bound to heat shock proteins before homodimer. Therefore, AR can bind to the ligand such as endogenous androgens, and then form a homodimer. Subsequently, the homodimer moves into to the nucleus and activates target gene transcription, regulating cell proliferation [125, 126]. This process is showed in Fig. 3. Base on the above characteristics, anti-androgens, selective androgen receptor modulators and 7-hydroxytestosterone are effective for patients with AR positive breast cancer, including AR positive TNBC. Bicalutamide is the first AR antagonist which was clinically evaluated in 2013. The phase II study exploring bicalutamide has proved that antiandrogen therapy is effective in treating patients with AR positive breast cancer [127]. Further, the antitumor activity and safety of enzalutamide in patients with AR positive TNBC has been assessed in another phase II trial (NCT01889238). The results showed that the clinical benefit rate at 16 weeks was $25 \%$, and the median overall survival was 12.7 months, meaning considerable beneficial therapeutic efficiency. And the only treatmentrelated grade 3 or higher $\mathrm{AE}$ was fatigue with an incidence $>2 \%$ [128]. Except for the above two kinds of AR antagonist, a past study found that LAR cell lines were especially sensitive to NVP-BEZ235, a dual PI3K/mTOR inhibitor, which can be explained by PIK3CA-activating mutations in all LAR cell lines [5]. For TNBC patients with AR positive, they benefit not only from monotherapy but also combination therapy. A study shows that compared with AR negative TNBC, activated PIK3CA mutations are abundant in TNBC with AR positive, and the combination of PI3K inhibitors and AR antagonist can significantly inhibit the growth and viability of LAR cell line models [129]. Moreover, it is proven that the combination of bicalutamide with the EGFR inhibitors more effectively decreases the expression of AR compared with each agent given alone, and suppress cell proliferation of tumor [129]. Therefore, recent topic has been focused on the combination therapy of AR pathway inhibition in TNBC. It's probably also worth noting that how to define AR positive. Now patients selected for clinical trials are mainly LAR subtype defined by gene expression profiling. So, can we precisely guide therapy based on AR expression levels?We need more evidence to explore.

\section{Antibody-drug conjugates (ADC)}

ADCs' are immunoconjugate agents with specificity and the high potency, which can deliver chemotherapy drugs to cancer cells precisely. ADCs consist of three components, a highly efficient cytotoxic payload, an antibody and a linker connecting the former two components [130]. In the process of transport, ADC binds to target antigens on tumor cell surface and then enter the target cell via receptor-mediated endocytosis. After entering the cell, ADCs are degraded by lysosomes, in which the linker cleaves, leading to the release of payloads into cytoplasm. This process is illustrated in Fig. 3. Regarding the efficacy in the treatment of solid tumors, ADCs have shown great clinical prospect, they 
are rarely used in TNBC patients because of lack of effective and appropriate targets [131]. Till now, there have been three ADCs approved by FDA for breast cancer, two of which, ado-trastuzumab emtansine and fam-trastuzumab deruxtecan, target HER2 [132]. Another one, sacituzumab govitecan (SG), is approved for patients with metastatic TNBC who have received at least 2 kinds of therapy before. SG, composed of an anti-Trop- 2 antibody and active metabolite of irinotecan, targets the antigen trophoblast cell-surface antigen 2 (Trop-2), which is a glycoprotein expressed by many solid cancers [133]. Preclinical trials show that Trop-2 expresses in all breast cancer subtypes, particularly in TNBC [134]. Furthermore, in a clinical trial in patients with metastasis TNBC, SG reveals manageable safety, with $33 \%$ objective response rates and a mPFS of 5.5 months [135]. The subsequent phase III ASCENT trial confirms improvements in both PFS and OS, which accelerates US FDA approval of SG [136]. Another phase III study, SASCIA, assesses the therapeutic effect of SG in primary HER2 negative breast cancer patients (HR + or TNBC) with high relapse risk after standard neoadjuvant treatment (NCT04595565). In addition, more ADCs targeting novel antigens in TNBC patients are in clinical trials, including LIV-1, receptor tyrosine kinase-like orphan receptor 1 (ROR1) and ROR2.
Compared with conventional chemotherapy, ADC can preciously target the tumor cells, which provide a broad therapeutic window. For TNBC with high heterogeneity, $\mathrm{ADC}$ is more suitable for combination therapy with other targeted agents to enhance synergy. Thus, it's promising research to explore more combination strategy. Besides, more attention should be paid to its toxicities. In addition to off-target effects, AEs are related to payload effectiveness. ADCs combined with non-overlapping toxic immune checkpoint inhibitors (ICIs) may be a potential option.

\section{Immune checkpoint inhibitors (ICls)}

Immune checkpoints, most notably cytotoxic T-lymphocyte-associated protein 4 (CTLA-4) and programmed cell death protein 1 (PD-1), inhibit effector T lymphocytes to limit the anti-tumor autoimmune response [137]. PD-L1 expressing in the tumor cells binds to PD-1 which is on the surface of $\mathrm{T}$ cell and prevents $\mathrm{T}$ cell activation [138]. The tumor-infiltrating lymphocytes also can express highly PD-1, and both of them are increased in TNBC [139]. Therefore, ICIs can enhance the anti-tumor immune responses to kill tumor cells [140]. These processes are illustrated in Fig. 4. ICIs including monoclonal antibodies against PD-1 (pembrolizumab, nivolumab), PD-L1 (atezolizumab, durvalumab, avelumab), and

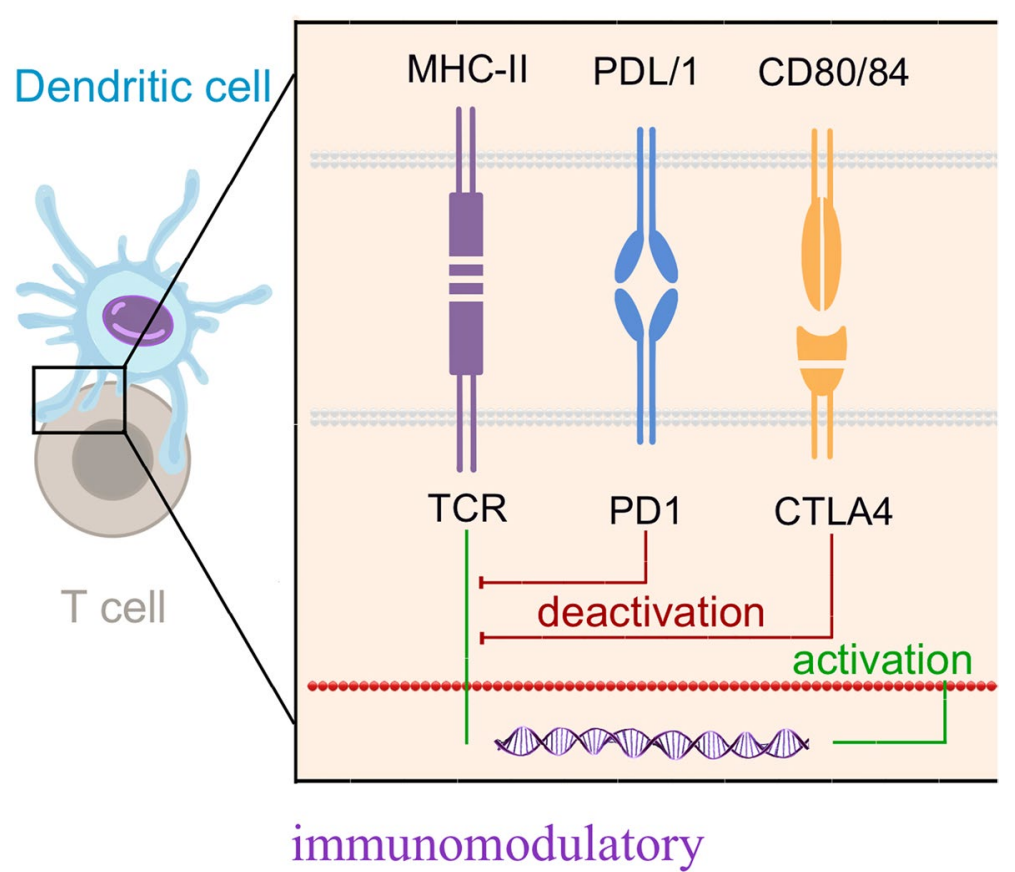

Fig. 4 Immune checkpoint inhibitors for the treatment of TNBC. Immune checkpoints limit the anti-tumor autoimmune response by inhibiting effector T lymphocytes. PD-L1 expressing in the tumor cells binds to PD-1 which is on the surface of T cell and prevents T cell activation. The tumor-infiltrating lymphocytes also can express highly PD-1, and both of them are increased in TNBC. ICls can enhance the anti-tumor immune responses to kill tumor cell 
CTLA-4 (ipilimumab) have shown promising results in treating many types of cancer. Nowadays, there have been two ICIs approved by the FDA. One is Atezolizumab in 2019, which is approved in combination with nab-paclitaxel to treat unresectable locally advanced or metastatic TNBC patients with PD-L1 positive in 2019 [141]. In a phase III clinical trial (KEYNOTE-355), the other ICI, pembrolizumab plus chemotherapy distinctly improved the PFS of patients with metastatic TNBC, compared with placebo plus chemotherapy [142]. And therefore, Pembrolizumab, was approved in 2020 to treat metastatic TNBC patients with PD-L1-expressing in combination with chemotherapy [143]. In addition to combining chemotherapy, the combination of ICIs and targeted agents in the treatment of TNBC also has great clinical potential. For example, PARPis can lead to cell death through inhibiting the repair of DNA damage. Surprisingly, repressed PARP enhances PD-L1 expression in TNBC cells, creating conditions for ICIs to target [144]. In a clinical trial, niraparib-pembrolizumab shows potential anti-tumor activity for patients with advanced or metastatic TNBC, and significantly higher response rates in patients with BRCA mutations (NCT02657889) [98]. Furthermore, many other ICIs are also being studied in clinical trials and promising predictive biomarkers for immunotherapy in TNBC are also very potential in clinical practice.

Combination with other therapies or factors can also augment the efficacy of ICIS. The first of the therapy is Dysregulated Tumor Vasculature. When the tumor expands to a certain extent, tumor cells within the tumor core become increasingly hypoxic, and expresses the Angiogenic Growth Factors, which is associated with the expression of hypoxic induced transcription factors $[145,146]$. Under the hypoxia conditions of tumor microenvironment, the metabolic demand balance of angiogenesis and surrounding tissue is destroyed, causes angiogenesis [146]. In the IMbrave150phase III clinical trial (NCT03434379), the anti-PD-1 reagent, combined with an anti-angiogenic agent, had a clinically prominent amelioration in $\mathrm{mPFS}$, compared with the protein kinase inhibitor [147]. The other one is Interleukin-8 and CXCR1 / CXCR2. IL-8 can bind to CXCR1 and CXCR2 G-Protein coupled receptors on granulocytes, monocytes, and endothelial cells [148, 149]. Some research indicated that anti-CXCR2 monoclonal antibody caused remarkable tumor-resistance activity, even after delayed anti-PD-1 treatment [150]. The Phase I Trial for HumaxIL8 (NCT 02,536,469) indicates that serum IL-8 levels have decreased significantly in patients who use IL-8 as a prognostic biomarker to inhibit anti-PD-1 checkpoints. This indicates that IL-8 suppression can be regarded as potential candidates for ICI combination treatment [151].
Further, Cluster of differentiation 73, normally expressed on Treg cells, is an ectonucleotidase that dephosphorylates extracellular AMP to adenosine [152]. It can promote the adhesion of lymphocytes restrain the migration of lymphocytes and reduce lymph nodes [153]. We summarize partial of clinical trials with results on ICIs in Table 2.

\section{Conclusion and perspective}

TNBC is still the refractory subtype of breast cancer with the worst prognosis due to the resistance and insensitivity to radiotherapy and chemotherapy. Now, surgery combined with radiotherapy and chemotherapy is the main treatment for patients with TNBC. Good news is that several dysfunctional signaling pathways and proteins have been observed in patients with TNBC, such as PI3K/AKT/mTOR, MAPK signaling pathways, CDKs 4/6, notching signaling, PARP, EMT-associated pathways and AR, which can be used as novel therapeutic targets and some specific agents have received FDA approval. And with improved knowledge of immune checkpoints, effective immunotherapy has gradually applied in TNBC patients. At present, there are amounts of ongoing trials testing the efficacy of targeted agents and ICIs for patients with TNBC. It's a long and tough way for clinicians to make effective and safe drugs into clinics.

Patients with TNBC show different clinical response to treatment due to the high heterogeneity of TNBC. There are six subtypes of TNBC, and patients with different subtypes have been found to show different responses to drugs. For example, as mentioned above, compares with other subtypes, LAR subtype is more sensitive to CDK4/6 inhibitors and AR antagonist. Immunotherapy is more appropriate for PD-L1 positive patients. For both clinicians and patients, how to predict the clinical efficacy of drugs, and which therapeutic schedule to choose is in need of guidance. Thus, future development of new predictive biomarkers is urgently needed for selecting patients who will benefit most from a particular therapy.

Combination therapy has shown better performance than monotherapy in multiple clinical trials. For example, the concomitant administration of chemotherapy with TGF- $\beta$-targeted drugs which have been found to improve the chemotherapy-resistance and recurrence, the combination of AR antagonists with PI3K/mTOR inhibitors, the combination of ICIs and PARPis which can enhance PD-L1 expression in TNBC cells, and other combinations are in clinical trials. However, the mechanisms of combination therapies are not fully understood. More molecular research is necessary to figure out the mechanisms of combination therapy to explore better combination options, including but not limited to the combination among immunotherapy, targeted therapy, 
Table 2 Partial clinical trials of ICls involving patients with TNBC

\begin{tabular}{|c|c|c|c|c|c|c|c|}
\hline \multirow[t]{2}{*}{ Pathway } & \multirow[t]{2}{*}{ NCT } & \multirow[t]{2}{*}{ Phase } & \multicolumn{2}{|l|}{ Results } & \multicolumn{2}{|l|}{ Treatment } & \multirow[t]{2}{*}{ Reference } \\
\hline & & & Group 1 & Group 2 & Group 1 & Group 2 & \\
\hline ICls (Anti PD-1) & NCT03125902 & III & $\begin{array}{l}\text { mPFS: } \\
6.0 \text { months } \\
\text { mOS: } \\
22.1 \text { months } \\
\text { ORR: } 63 \%(95 \% \\
\text { Cl, 56\%-70\%) }\end{array}$ & $\begin{array}{l}\text { mPFS: } 5.7 \text { months } \\
\text { mOS: } 28.3 \text { months } \\
\text { ORR: } 55 \%(95 \% \text { Cl, } 45 \%-65 \%)\end{array}$ & Paclitaxel + Atezolizumab & $\begin{array}{l}\text { Paclitaxel + Pla- } \\
\text { cebo }\end{array}$ & [154] \\
\hline ICls (Anti PD-1) & NCT03197935 & III & $\begin{array}{l}\text { pCR: } 58 \% \\
\text { treatment- } \\
\text { related serious } \\
\text { adverse events: } \\
23 \%\end{array}$ & $\begin{array}{l}\text { pCR: } 41 \% \\
\text { treatment-related serious adverse } \\
\text { events: } 16 \%\end{array}$ & $\begin{array}{l}\text { Atezolizumab + Chemo- } \\
\text { therapy (nab- } \\
\text { paclitaxel + doxoru- } \\
\text { bicin + cyclophospha- } \\
\text { mide) }\end{array}$ & $\begin{array}{l}\text { Placebo + Chem- } \\
\text { otherapy } \\
\text { (nab-pacli- } \\
\text { taxel + doxoru- } \\
\text { bicin + cyclo- } \\
\text { phosphamide) }\end{array}$ & [155] \\
\hline ICls (Anti PD-1) & NCT03036488 & $\|$ & $\begin{array}{l}\text { PCR: } 64.8 \% \text { (95\% } \\
\text { Cl, } 59.9 \%-69.5 \%) \\
\text { incidence of } \\
\text { treatment- } \\
\text { related adverse } \\
\text { events of grade } 3 \\
\text { or higher: } 78.0 \%\end{array}$ & $\begin{array}{l}\text { pCR:51.2\%(95\%Cl,44.1\%-58.3\%) } \\
\text { incidence of treatment-related } \\
\text { adverse events of grade } 3 \text { or } \\
\text { higher: } 73.0 \%\end{array}$ & $\begin{array}{l}\text { Pembrolizumab + Chemo- } \\
\text { therapy (paclitaxel + car- } \\
\text { boplatin) }\end{array}$ & $\begin{array}{l}\text { Placebo + Chem- } \\
\text { otherapy } \\
\text { (paclitaxel + car- } \\
\text { boplatin) }\end{array}$ & [156] \\
\hline ICls (Anti PD-1) & NCT02622074 & । & $\begin{array}{l}\text { pCR: } 60 \%(95 \% \mathrm{Cl} \\
49 \%-71 \%)\end{array}$ & & $\begin{array}{l}\text { Pembrolizumab + Chemo- } \\
\text { therapy }\end{array}$ & & [157] \\
\hline $\begin{array}{l}\text { ICls (Anti PD-1) } \\
\text { AXL inhibitor }\end{array}$ & NCT03184558 & 1 & $\begin{array}{l}\text { PFS: } 13.1 \text { months } \\
(95 \% \mathrm{Cl}, \\
12.4-18.3) \\
\text { OS: } 32.0 \text { months } \\
(95 \% \mathrm{Cl}, 13.6- \\
37.1) \\
\text { DCR: } 3.4 \%\end{array}$ & & $\begin{array}{l}\text { Pembrolizumab + Bem- } \\
\text { centinib }\end{array}$ & & \\
\hline $\begin{array}{l}\text { ICls (Anti PD-1) } \\
\text { IDO1 inhibitor }\end{array}$ & NCT02178722 & $|/| \mid$ & ORR: $11.1 \%$ & & MK-3475 + INCB024360 & & \\
\hline $\begin{array}{l}\text { ICls (Anti PD-1) } \\
\text { IDO1 inhibitor } \\
\text { GITR inhibitor }\end{array}$ & NCT03277352 & $|/| \mid$ & $\begin{array}{l}\text { ORR: } 30 \% \\
\text { DCR: } 70 \% \\
\text { OS: } 25.59 \text { months }\end{array}$ & & $\begin{array}{l}\text { Pembrolizumab + Epaca- } \\
\text { dostat + INCAGN01876 }\end{array}$ & & \\
\hline ICls (Anti PD-1) & NCT01848834 & । & ORR: $18.5 \%$ & & Pembrolizumab & & [158] \\
\hline ICls (Anti PD-L1) & NCT01375842 & 1 & $\begin{array}{l}\text { ORR in first-line: } \\
24 \% \\
\text { ORR in second- } \\
\text { line: } 6 \%\end{array}$ & & Atezolizumab & & [159] \\
\hline ICls (Anti PD-1) & NCT02838823 & 1 & $\begin{array}{l}\text { ORR: } 5 \% \\
\text { mPFS: } \\
1.8 \text { months ( } 95 \% \\
\text { Cl, } 1.4-4.6)\end{array}$ & & $\begin{array}{l}\text { Humanized anti-PD-1 } \\
\text { monoclonal antibody }\end{array}$ & & [160] \\
\hline ICls (Anti PD-L1) & $\begin{array}{l}\text { NCT02447003 } \\
\text { (Group A) }\end{array}$ & $\|$ & $\begin{array}{l}\text { mPFS: } \\
2.0 \text { months ( } 95 \% \\
\text { Cl,1.9-2.0) } \\
\text { mOS: } 9.0 \text { months } \\
(95 \% \mathrm{Cl}, 7.6-11.2)\end{array}$ & & Pembrolizumab & & [161] \\
\hline ICls (Anti PD-L1) & $\begin{array}{l}\text { NCT02447003 } \\
\text { (Group B) }\end{array}$ & $\|$ & $\begin{array}{l}\text { ORR: } 21.4 \%(95 \% \\
\text { Cl } 13.9-31.4)\end{array}$ & & Pembrolizumab & & [162] \\
\hline ICls (Anti PD-1) & NCT02499367 & $\|$ & $\begin{array}{l}\text { ORR: 20.0\%; } \\
\text { mPFS: } \\
1.9 \text { months }\end{array}$ & & Nivolumab & & [163] \\
\hline ICls (Anti PD-L1) & NCT02555657 & III & $\begin{array}{l}\text { mOS: } \\
12.7 \text { months } \\
(95 \% \mathrm{Cl}, 9.9-16.3)\end{array}$ & $\begin{array}{l}\text { mOS: } 11.6 \text { months }(95 \% \mathrm{Cl} \text {, } \\
8.3-13.7)\end{array}$ & Pembrolizumab & Chemotherapy & {$[164]$} \\
\hline
\end{tabular}


and chemoradiotherapy. Furthermore, for combination therapy, the sequence and timing of medications are also worth exploring. Whether different modes of administration will affect the therapeutic effect for the same combination. Postoperative adjuvant, neoadjuvant, or maintenance therapy. Current clinical evidence is insufficient to determine whether postoperative adjuvant, neoadjuvant, or sequential therapy is more satisfactory. And what's the administration sequence of sequential therapy?

In addition to the development of new drugs, AEs and resistance are also worth studying. For some drugs, AEs limit their application in clinical. This happens a lot when many patients terminate treatment because they can't tolerate treatment-related side effects. Serious side effects can even lead to death. So, more attention should also be paid to AEs early in trials. After drugs are widely applied to the clinic, patients are prone to resistance in the later course of treatment which is a great challenge for clinical application. Resistance has been observed with several targeted agents in patients with other solid tumors. Except for further figuring out dominant mechanisms of resistance within TNBC, new predictive biomarkers are also necessary to predict resistance. It's essential to ensure the long-term safety and tolerability of the therapeutic regimens.

In spite of extensive clinical studies on precise medicine in TNBC, whether drugs based on signaling pathways and immune checkpoints can be applied widely in clinical practice or whether they can really improve PFS of the TNBC patients need more data and studies. In the future, we hope to achieve the individualized and precise treatment of TNBC through targeted therapy and immunotherapy.

\footnotetext{
Abbreviations

ADC: Antibody-drug conjugate; AE: Adverse event; APC: Adenomatous polyposis coli; AR: Androgen receptor; CDK: Cyclin-dependent kinase; CK1a: Casein kinase 1a; CSC: Cancer stem-like cell; CSF-1: Colony-stimulating factor-1; CTLA-4: T-lymphocyte-associated protein 4; DCP: Disease Control Rate; DII: Delta-like; Dvl: Dishevelled; FDA: U.S. Food and Drug Administration; FGFR: Fibroblast growth factor receptor; Fzds: Frizzleds; EGFR: Epidermal growth factor receptor; EMT: Epithelial-mesenchymal transition; ER: Estrogen receptor; ERK: Extracellular signal-regulated kinases; GSI: $\gamma$-Secretase inhibitors

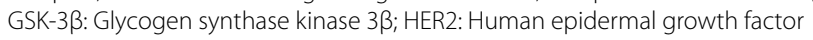
receptor 2; HR: Hormone receptor; HSP: Heat shock proteins; IGFR: Insulin-like growth factor receptor; JAG: Jagged; LAR: Luminal androgen receptor; LRP5/6: Lipoprotein receptor-related protein 5/6; MAPK: Mitogen-activated protein kinase; mPFS: Median progression free survival; mTOR: Mammalian target of rapamycin; OS: Overall survival; ORR: Objective Response Rate; PARP: Poly(ADP)-Ribose Polymerase; PARPis: Poly-(ADP)-Ribose Polymerase inhibitors; pCR: Pathological complete response; PD-1: Programmed cell death protein 1; PD-L1: Programmed cell death-ligand 1; PFS: Progression free survival; PI3K: Phosphatidylinositol-3-kinase; PIP2: Phosphorylates 4,5-phosphoinositide; PIP3: Phosphorylates 3,4,5-phosphoinositide; PR: Progesterone receptor; PTEN: Phosphatase and tension homolog; Rb: Retinoblastoma protein; RR: Response rate; RTK: Receptor tyrosine kinase; SG: Sacituzumab govitecan; TEAEs: Treatment-emergent adverse events; TGF- $\beta$ : Transforming growth factor-beta; TKI:Tyrosine kinase inhibitor; TNBC: Triple negative breast cancer; Trop-2:
}

Trophoblast cell-surface antigen 2; VEGFR: Vascular endothelial growth factor receptor; WIF-1: Wnt inhibitory factor 1 .

\section{Supplementary Information}

The online version contains supplementary material available at https://doi. org/10.1186/s43556-022-00071-6.

Additional file 1: Table 1. Trials of therapy in triple-negative breast cancer.

\section{Acknowledgements}

Thanks to all authors for their contributions to the manuscript.

\section{Authors' contributions}

All authors contributed to the study conception and design. Literature review, data collection and were performed by [Ruoning YANG], [Yueyi LI] and [Hang WANG]. The first draft of the manuscript was written by [Ruoning YANG] and [Xuelei MA]. [Taolin Qin] edited tables and figures. and all authors commented on previous versions of the manuscript. All authors read and approved the final manuscript.

\section{Funding}

This study received no financial support.

\section{Availability of data and materials}

Not applicable.

Code availability

Not applicable.

\section{Declarations}

Ethics approval and consent to participate

Not applicable.

Consent for publication

Not applicable.

Competing interests

All authors have declared that no competing interest exists.

\section{Author details}

${ }^{1}$ Department of Biotherapy, State Key Laboratory of Biotherapy,Cancer Center, West China Hospital, 37 Guoxue Alley, Chengdu 610041, PR, China. ²Department of Breast Surgery, Clinical Research Center for Breast, West China Hospital, Sichuan University, Chengdu 610041, China. ${ }^{3}$ West China Hospital, West China Medical School Sichuan University, Chengdu, PR, China.

Received: 11 November 2021 Accepted: 9 February 2022

Published online: 04 March 2022

\section{References}

1. Sung H, Ferlay J, Siegel RL, Laversanne M, Soerjomataram I, Jemal A, et al. Global Cancer Statistics 2020: GLOBOCAN Estimates of Incidence and Mortality Worldwide for 36 Cancers in 185 Countries. CA Cancer J Clin. 2021;71(3):209-49. https://doi.org/10.3322/caac.21660.

2. Borri F, Granaglia A. Pathology of triple negative breast cancer. Semin Cancer Biol. 2021;72:136-45. https://doi.org/10.1016/j.semcancer.2020. 06.005 .

3. Perou CM, Sørlie T, Eisen MB, van de Rijn M, Jeffrey SS, Rees CA, et al. Molecular portraits of human breast tumours. Nature. 2000;406(6797):747-52. https://doi.org/10.1038/35021093.

4. Brenton JD, Carey LA, Ahmed AA, Caldas C. Molecular classification and molecular forecasting of breast cancer: ready for clinical application? J Clin Oncol. 2005;23(29):7350-60. https://doi.org/10.1200/jco.2005.03. 3845 . 
5. Lehmann BD, Bauer JA, Chen X, Sanders ME, Chakravarthy AB, Shyr Y, et al. Identification of human triple-negative breast cancer subtypes and preclinical models for selection of targeted therapies. J Clin Invest. 2011;121(7):2750-67. https://doi.org/10.1172/jci45014.

6. Agarwal G, Nanda G, Lal P, Mishra A, Agarwal A, Agrawal V, et al. Outcomes of Triple-Negative Breast Cancers (TNBC) Compared with Non-TNBC: Does the Survival Vary for All Stages? World I Surg. 2016;40(6):1362-72. https://doi.org/10.1007/s00268-016-3422-4.

7. Kaplan HG, Malmgren JA. Impact of triple negative phenotype on breast cancer prognosis. Breast J. 2008;14(5):456-63. https://doi.org/10. 1111/j.1524-4741.2008.00622.x.

8. Wang L, Zhai Q, Lu Q, Lee K, Zheng Q, Hong R, et al. Clinical genomic profiling to identify actionable alterations for very early relapsed triplenegative breast cancer patients in the Chinese population. Ann Med. 2021;53(1):1358-69. https://doi.org/10.1080/07853890.2021.1966086.

9. Lin NU, Claus E, Sohl J, Razzak AR, Arnaout A, Winer EP. Sites of distant recurrence and clinical outcomes in patients with metastatic triplenegative breast cancer: high incidence of central nervous system metastases. Cancer. 2008;113(10):2638-45. https://doi.org/10.1002/ cncr.23930.

10. Ademuyiwa FO, Chen I, Luo J, Rimawi MF, Hagemann IS, Fisk B, et al. Immunogenomic profiling and pathological response results from a clinical trial of docetaxel and carboplatin in triple-negative breast cancer. Breast cancer research and treatment. 2021;189(1):187-202. https:// doi.org/10.1007/s10549-021-06307-3.

11. Clark AS, McAndrew NP, Troxel A, Feldman M, Lal P, Rosen M, et al. Combination Paclitaxel and Palbociclib: Results of a Phase I Trial in Advanced Breast Cancer. Clinical cancer research : an official journal of the American Association for Cancer Research. 2019;25(7):2072-9. https://doi.org/ 10.1158/1078-0432.CCR-18-0790.

12. Shafique M, Ismail-Khan R, Extermann M, Sullivan D, Goodridge D, Boulware D, et al. A Phase II Trial of Selinexor (KPT-330) for Metastatic Triple-Negative Breast Cancer. Oncologist.2019;24(7) https://doi.org/10. 1634/theoncologist.2019-0231

13. Sharma P, Kimler BF, O'Dea A, Nye L, Wang YY, Yoder R, et al. Randomized Phase II Trial of Anthracycline-free and Anthracycline-containing Neoadjuvant Carboplatin Chemotherapy Regimens in Stage I-III Triple-negative Breast Cancer (NeoSTOP). Clinical cancer research : an official journal of the American Association for Cancer Research. 2021:27(4):975-82. https://doi.org/10.1158/1078-0432.CCR-20-3646.

14. Oliveira M, Saura C, Nuciforo P, Calvo I, Andersen J, Passos-Coelho JL, et al. FAIRLANE, a double-blind placebo-controlled randomized phase II trial of neoadjuvant ipatasertib plus paclitaxel for early triple-negative breast cancer. Annals of oncology : official journal of the European Society for Medical Oncology. 2019;30(8):1289-97. https://doi.org/10. 1093/annonc/mdz177.

15. Schmid P, Abraham J, Chan S, Wheatley D, Brunt AM, Nemsadze G, et al. Capivasertib Plus Paclitaxel Versus Placebo Plus Paclitaxel As First-Line Therapy for Metastatic Triple-Negative Breast Cancer: The PAKT Trial. Journal of clinical oncology : official journal of the American Society of Clinical Oncology. 2020;38(5):423-33. https://doi.org/10.1200/JCO.19. 00368.

16. Turner N, Dent RA, O'Shaughnessy J, Kim S-B, Isakoff SJ, Barrios C, et al. Ipatasertib plus paclitaxel for PIK3CA/AKT1/PTEN-altered hormone receptor-positive HER2-negative advanced breast cancer: primary results from cohort B of the IPATunity 130 randomized phase 3 trial. Breast cancer research and treatment.2021;doi:https://doi.org/10.1007/ s10549-021-06450-x

17. Garrido-Laguna I, Krop I, Burris HA, Hamilton E, Braiteh F, Weise AM, et al. First-in-human, phase I study of PF-06647263, an anti-EFNA4 calicheamicin antibody-drug conjugate, in patients with advanced solid tumors. Int J Cancer. 2019;145(7):1798-808. https://doi.org/10.1002/ijc. 32154.

18. Bardia A, Mayer IA, Vahdat LT, Tolaney SM, Isakoff SJ, Diamond JR, et al. Sacituzumab Govitecan-hziy in Refractory Metastatic Triple-Negative Breast Cancer. The New England journal of medicine. 2019;380(8):74151. https://doi.org/10.1056/NEJMoa1814213.

19. Bardia A, Tolaney SM, Punie K, Loirat D, Oliveira M, Kalinsky K, et al. Biomarker analyses in the phase III ASCENT study of sacituzumab govitecan versus chemotherapy in patients with metastatic triple-negative breast cancer. Annals of oncology : official journal of the European
Society for Medical Oncology. 2021;32(9):1148-56. https://doi.org/10. 1016/j.annonc.2021.06.002.

20. Pottier C, Fresnais M, Gilon M, Jérusalem G, Longuespée R, Sounni NE. Tyrosine Kinase Inhibitors in Cancer: Breakthrough and Challenges of Targeted Therapy. Cancers (Basel).2020;12(3) https://doi.org/10.3390/ cancers12030731

21. Robinson DR, Wu YM, Lin SF. The protein tyrosine kinase family of the human genome. Oncogene. 2000;19(49):5548-57. https://doi.org/10. 1038/sj.onc.1203957.

22. Schlessinger J. Cell signaling by receptor tyrosine kinases. Cell. 2000;103(2):211-25. https://doi.org/10.1016/s0092-8674(00)00114-8.

23. Scaltriti M, Baselga J. The epidermal growth factor receptor pathway: a model for targeted therapy. Clin Cancer Res. 2006;12(18):5268-72. https://doi.org/10.1158/1078-0432.Ccr-05-1554.

24. Yarden Y, Sliwkowski MX. Untangling the ErbB signalling network. Nat Rev Mol Cell Biol. 2001;2(2):127-37. https://doi.org/10.1038/35052073.

25. Wieduwilt MJ, Moasser MM. The epidermal growth factor receptor family: biology driving targeted therapeutics. Cell Mol Life Sci. 2008;65(10):1566-84. https://doi.org/10.1007/s00018-008-7440-8.

26. Costa R, Shah AN, Santa-Maria CA, Cruz MR, Mahalingam D, Carneiro BA, et al. Targeting Epidermal Growth Factor Receptor in triple negative breast cancer: New discoveries and practical insights for drug development. Cancer Treat Rev. 2017;53:111-9. https://doi.org/10.1016/j.ctrv. 2016.12.010.

27. Iancu G, Serban D, Badiu CD, Tanasescu C, Tudosie MS, Tudor C, et al. Tyrosine kinase inhibitors in breast cancer (Review). Exp Ther Med. 2022;23(2):114. https://doi.org/10.3892/etm.2021.11037.

28. Barton-Burke M, Ciccolini K, Mekas M, Burke S. Dermatologic Reactions to Targeted Therapy: A Focus on Epidermal Growth Factor Receptor Inhibitors and Nursing Care. Nurs Clin North Am.2017;52(1) https://doi. org/10.1016/j.cnur.2016.11.005

29. Elkabets M, Pazarentzos E, Juric D, Sheng Q, Pelossof RA, Brook S, et al. AXL mediates resistance to PI3Ka inhibition by activating the EGFR/ $\mathrm{PKC} / \mathrm{mTOR}$ axis in head and neck and esophageal squamous cell carcinomas. Cancer Cell. 2015;27(4):533-46. https://doi.org/10.1016/j.ccell. 2015.03.010.

30. Shu S, Wu HJ, Ge JY, Zeid R, Harris IS, Jovanović B, et al. Synthetic Lethal and Resistance Interactions with BET Bromodomain Inhibitors in TripleNegative Breast Cancer. Mol Cell. 2020;78(6):1096-1113.e8. https://doi. org/10.1016/j.molcel.2020.04.027.

31. You KS, Yi YW, Cho J, Park JS, Seong YS. Potentiating Therapeutic Effects of Epidermal Growth Factor Receptor Inhibition in Triple-Negative Breast Cancer. Pharmaceuticals (Basel).2021;14(6) https://doi.org/10. 3390/ph14060589

32. Chen H, Lu W, Zhang Y, Zhu X, Zhou J, Chen Y. A Bayesian network meta-analysis of the efficacy of targeted therapies and chemotherapy for treatment of triple-negative breast cancer. Cancer Med. 2019:8(1):383-99. https://doi.org/10.1002/cam4.1892.

33. D'Alfonso TM, Hannah J, Chen Z, Liu Y, Zhou P, Shin SJ. Axl receptor tyrosine kinase expression in breast cancer. J Clin Pathol. 2014;67(8):690-6. https://doi.org/10.1136/jclinpath-2013-202161.

34. Sheridan C. First Axl inhibitor enters clinical trials. Nat Biotechnol. 2013:31(9):775-6. https://doi.org/10.1038/nbt0913-775a.

35. Khan MA, Jain VK, Rizwanullah M, Ahmad J, Jain K. PI3K/AKT/mTOR pathway inhibitors in triple-negative breast cancer: a review on drug discovery and future challenges. Drug Discov Today. 2019;24(11):218191. https://doi.org/10.1016/j.drudis.2019.09.001.

36. Cangemi A, Fanale D, Rinaldi G, Bazan V, Galvano A, Perez A, et al. Dietary restriction: could it be considered as speed bump on tumor progression road? Tumour Biol. 2016;37(6):7109-18. https://doi.org/10. 1007/s13277-016-5044-8.

37. Rameh LE, Cantley LC. The role of phosphoinositide 3-kinase lipid products in cell function. J Biol Chem. 1999;274(13):8347-50. https://doi.org/ 10.1074/jbc.274.13.8347.

38. Franke TF, Kaplan DR, Cantley LC, Toker A. Direct regulation of the Akt proto-oncogene product by phosphatidylinositol-3,4-bisphosphate. Science. 1997;275(5300):665-8. https://doi.org/10.1126/science.275. 5300.665.

39. Salmena L, Carracedo A. Pandolfi pp. Tenets of PTEN tumor suppression Cell. 2008;133(3):403-14. https://doi.org/10.1016/j.cell.2008.04.013. 
40. Inoki K, Li Y, Zhu T, Wu J, Guan KL. TSC2 is phosphorylated and inhibited by Akt and suppresses mTOR signalling. Nat Cell Biol. 2002;4(9):648-57. https://doi.org/10.1038/ncb839.

41. Meric-Bernstam F, Gonzalez-Angulo AM. Targeting the mTOR signaling network for cancer therapy. J Clin Oncol. 2009;27(13):2278-87. https:// doi.org/10.1200/jco.2008.20.0766.

42. Tobin NP, Harrell JC, Lövrot J, Egyhazi Brage S, Frostvik Stolt M, Carlsson $L$, et al. Molecular subtype and tumor characteristics of breast cancer metastases as assessed by gene expression significantly influence patient post-relapse survival. Ann Oncol. 2015;26(1):81-8. https://doi. org/10.1093/annonc/mdu498.

43. Jacinto E, Facchinetti V, Liu D, Soto N, Wei S, Jung SY, et al. SIN1/MIP1 maintains rictor-mTOR complex integrity and regulates Akt phosphorylation and substrate specificity. Cell. 2006;127(1):125-37. https://doi. org/10.1016/j.cell.2006.08.033.

44. Sarbassov DD, Ali SM, Kim DH, Guertin DA, Latek RR, ErdjumentBromage $\mathrm{H}$, et al. Rictor, a novel binding partner of mTOR, defines a rapamycin-insensitive and raptor-independent pathway that regulates the cytoskeleton. Curr Biol. 2004;14(14):1296-302. https://doi.org/10. 1016/j.cub.2004.06.054.

45. Comprehensive molecular portraits of human breast tumours 2012 Nature 490741861 70https://doi.org/10.1038/nature11412

46. LoRusso PM. Inhibition of the PI3K/AKT/mTOR Pathway in Solid Tumors. J Clin Oncol. 2016;34(31):3803-15. https://doi.org/10.1200/jco.2014.59. 0018.

47. Shah SP, Roth A, Goya R, Oloumi A, Ha G, Zhao Y, et al. The clonal and mutational evolution spectrum of primary triple-negative breast cancers. Nature. 2012;486(7403):395-9. https://doi.org/10.1038/natur e10933.

48. Pascual J, Turner NC. Targeting the PI3-kinase pathway in triple-negative breast cancer. Ann Oncol. 2019;30(7):1051-60. https://doi.org/10.1093/ annonc/mdz133.

49. Lin J, Sampath D, Nannini MA, Lee BB, Degtyarev M, Oeh J, et al. Targeting activated Akt with GDC-0068, a novel selective Akt inhibitor that is efficacious in multiple tumor models. Clin Cancer Res. 2013;19(7):176072. https://doi.org/10.1158/1078-0432.Ccr-12-3072.

50. Shrivastava S, Kulkarni P, Thummuri D, Jeengar MK, Naidu VG, Alvala M, et al. Piperlongumine, an alkaloid causes inhibition of PI3 K/Akt/mTOR signaling axis to induce caspase-dependent apoptosis in human triplenegative breast cancer cells. Apoptosis. 2014;19(7):1148-64. https://doi. org/10.1007/s10495-014-0991-2.

51. Chin YR, Yoshida T, Marusyk A, Beck AH, Polyak K, Toker A. Targeting Akt3 signaling in triple-negative breast cancer. Cancer Res. 2014;74(3):96473. https://doi.org/10.1158/0008-5472.Can-13-2175.

52. Baselga J, Campone M, Piccart M, Burris HA 3rd, Rugo HS, Sahmoud $T$, et al. Everolimus in postmenopausal hormone-receptor-positive advanced breast cancer. N Engl J Med. 2012:366(6):520-9. https://doi. org/10.1056/NEJMoa1109653.

53. Generali D, Venturini S, Rognoni C, Ciani O, Pusztai L, Loi S, et al. A network meta-analysis of everolimus plus exemestane versus chemotherapy in the first- and second-line treatment of estrogen receptor-positive metastatic breast cancer. Breast Cancer Res Treat. 2015;152(1):95-117. https://doi.org/10.1007/s10549-015-3453-9.

54. Baselga J, Semiglazov V, van Dam P, Manikhas A, Bellet M, Mayordomo $J$, et al. Phase II randomized study of neoadjuvant everolimus plus letrozole compared with placebo plus letrozole in patients with estrogen receptor-positive breast cancer. J Clin Oncol. 2009;27(16):2630-7. https://doi.org/10.1200/jco.2008.18.8391.

55. Bachelot T, Bourgier C, Cropet C, Ray-Coquard I, Ferrero JM, Freyer G, et al. Randomized phase II trial of everolimus in combination with tamoxifen in patients with hormone receptor-positive, human epidermal growth factor receptor 2-negative metastatic breast cancer with prior exposure to aromatase inhibitors: a GINECO study. J Clin Oncol. 2012:30(22):2718-24. https://doi.org/10.1200/jco.2011.39.0708.

56. Lee JS, Yost SE, Blanchard S, Schmolze D, Yin HH, Pillai R, et al. Phase I clinical trial of the combination of eribulin and everolimus in patients with metastatic triple-negative breast cancer. Breast Cancer Res. 2019:21(1):119. https://doi.org/10.1186/s13058-019-1202-4.

57. Singh J, Novik Y, Stein S, Volm M, Meyers M, Smith J, et al. Phase 2 trial of everolimus and carboplatin combination in patients with triple negative metastatic breast cancer. Breast Cancer Res. 2014;16(2):R32. https://doi.org/10.1186/bcr3634.

58. Anand K, Patel T, Niravath P, Rodriguez A, Darcourt J, Belcheva A, et al. Targeting mTOR and DNA repair pathways in residual triple negative breast cancer post neoadjuvant chemotherapy. Sci Rep. 2021;11(1):82 https://doi.org/10.1038/s41598-020-80081-y.

59. Ibrahim YH, García-García C, Serra V, He L, Torres-Lockhart K, Prat A, et al. PI3K inhibition impairs BRCA1/2 expression and sensitizes BRCA-proficient triple-negative breast cancer to PARP inhibition. Cancer Discov. 2012;2(11):1036-47. https://doi.org/10.1158/2159-8290.Cd-11-0348.

60. Wainberg ZA, Alsina M, Soares HP, Braña I, Britten CD, Del Conte G, et al. A Multi-Arm Phase I Study of the PI3K/mTOR Inhibitors PF-04691502 and Gedatolisib (PF-05212384) plus Irinotecan or the MEK Inhibitor PD-0325901 in Advanced Cancer. Targeted oncology. 2017;12(6):77585. https://doi.org/10.1007/s11523-017-0530-5.

61. Giltnane JM, Balko JM. Rationale for targeting the Ras/MAPK pathway in triple-negative breast cancer. Discov Med. 2014;17(95):275-83.

62. Thompson KN, Whipple RA, Yoon JR, Lipsky M, Charpentier MS, Boggs AE, et al. The combinatorial activation of the PI3K and Ras/ MAPK pathways is sufficient for aggressive tumor formation, while individual pathway activation supports cell persistence. Oncotarget. 2015;6(34):35231-46. https://doi.org/10.18632/oncotarget.6159.

63. Sabova L, Kretova M, Luciakova K. New insights into the role of NF1 in cancer. Neoplasma. 2013;60(3):233-9. https://doi.org/10.4149/neo_ 2013_031.

64. Bartholomeusz C, Xie X, Pitner MK, Kondo K, Dadbin A, Lee J, et al. MEK Inhibitor Selumetinib (AZD6244; ARRY-142886) Prevents Lung Metastasis in a Triple-Negative Breast Cancer Xenograft Model. Mol Cancer Ther 2015;14(12):2773-81. https://doi.org/10.1158/1535-7163.Mct-15-0243.

65. Rinehart J, Adjei AA, Lorusso PM, Waterhouse D, Hecht JR, Natale RB, et al. Multicenter phase II study of the oral MEK inhibitor, Cl-1040, in patients with advanced non-small-cell lung, breast, colon, and pancreatic cancer. Journal of clinical oncology : official journal of the American Society of Clinical Oncology. 2004;22(22):4456-62.

66. Ono H, Horinaka M, Sukeno M, Morita M, Yasuda S, Nishimoto E, et al. Novel RAF/MEK inhibitor CH5126766/NS-6766 has efficacy in combination with eribulin for the treatment of triple-negative breast cancer. Cancer Sci. 2021;112(10):4166-75. https://doi.org/10.1111/cas.15071.

67. Hu Y, Gao J, Wang M, Li M. Potential Prospect of CDK4/6 Inhibitors in Triple-Negative Breast Cancer. Cancer Manag Res. 2021;13:5223-37. https://doi.org/10.2147/cmar.S310649.

68. Hochegger H, Takeda S, Hunt T. Cyclin-dependent kinases and cellcycle transitions: does one fit all? Nat Rev Mol Cell Biol. 2008;9(11):9106. https://doi.org/10.1038/nrm2510.

69. Pandey K, An H-J, Kim SK, Lee SA, Kim S, Lim SM, et al. Molecular mechanisms of resistance to CDK4/6 inhibitors in breast cancer: A review. Int J Cancer. 2019;145(5):1179-88. https://doi.org/10.1002/ijc.32020.

70. Finn RS, Crown JP, Lang I, Boer K, Bondarenko IM, Kulyk SO, et al. The cyclin-dependent kinase $4 / 6$ inhibitor palbociclib in combination with letrozole versus letrozole alone as first-line treatment of oestrogen receptor-positive, HER2-negative, advanced breast cancer (PALOMA-1/ TRIO-18): a randomised phase 2 study. Lancet Oncol. 2015;16(1):25-35. https://doi.org/10.1016/s1470-2045(14)71159-3.

71. Hortobagyi GN, Stemmer SM, Burris HA, Yap YS, Sonke GS, Paluch-Shimon S, et al. Ribociclib as First-Line Therapy for HR-Positive, Advanced Breast Cancer. N Engl J Med. 2016;375(18):1738-48. https://doi.org/10. 1056/NEJMoa1609709.

72. Dickler MN, Tolaney SM, Rugo HS, Cortés J, Diéras V, Patt D, et al. MONARCH 1, A Phase II Study of Abemaciclib, a CDK4 and CDK6 Inhibitor, as a Single Agent, in Patients with Refractory HR(+)/HER2(-) Metastatic Breast Cancer. Clin Cancer Res. 2017;23(17):5218-24. https://doi.org/10. 1158/1078-0432.Ccr-17-0754.

73. Asghar US, Barr AR, Cutts R, Beaney M, Babina I, Sampath D, et al. Single-Cell Dynamics Determines Response to CDK4/6 Inhibition in Triple-Negative Breast Cancer. Clin Cancer Res. 2017;23(18):5561-72. https://doi.org/10.1158/1078-0432.Ccr-17-0369.

74. Rao SS, Stoehr J, Dokic D, Wan L, Decker JT, Konopka K, et al. Synergistic effect of eribulin and CDK inhibition for the treatment of triple negative breast cancer. Oncotarget. 2017;8(48):83925-39. https://doi.org/10. 18632/oncotarget.20202. 
75. Patel JM, Goss A, Garber JE, Torous V, Richardson ET, Haviland MJ, et al. Retinoblastoma protein expression and its predictors in triple-negative breast cancer. NPJ Breast Cancer. 2020;6:19. https://doi.org/10.1038/ s41523-020-0160-4.

76. Giuli MV, Giuliani E, Screpanti I, Bellavia D, Checquolo S. Notch Signaling Activation as a Hallmark for Triple-Negative Breast Cancer Subtype. J Oncol. 2019;2019:8707053. https://doi.org/10.1155/2019/8707053.

77. Qiu M, Peng Q, Jiang I, Carroll C, Han G, Rymer I, et al. Specific inhibition of Notch1 signaling enhances the antitumor efficacy of chemotherapy in triple negative breast cancer through reduction of cancer stem cells. Cancer Lett. 2013;328(2):261-70. https://doi.org/10.1016/j.canlet.2012. 09.023 .

78. Al-Hussaini H, Subramanyam D, Reedijk M, Sridhar SS. Notch signaling pathway as a therapeutic target in breast cancer. Mol Cancer Ther. 2011;10(1):9-15. https://doi.org/10.1158/1535-7163.Mct-10-0677.

79. Weng AP, Millholland JM, Yashiro-Ohtani Y, Arcangeli ML, Lau A, Wai C, et al. c-Myc is an important direct target of Notch1 in T-cell acute lymphoblastic leukemia/lymphoma. Genes Dev. 2006;20(15):2096-109. https://doi.org/10.1101/gad.1450406.

80. Ronchini C, Capobianco AJ. Induction of cyclin D1 transcription and CDK2 activity by Notch(ic): implication for cell cycle disruption in transformation by Notch(ic). Mol Cell Biol. 2001;21(17):5925-34. https://doi. org/10.1128/mcb.21.17.5925-5934.2001.

81. Jamdade VS, Sethi N, Mundhe NA, Kumar P, Lahkar M, Sinha N. Therapeutic targets of triple-negative breast cancer: a review. Br J Pharmacol. 2015;172(17):4228-37. https://doi.org/10.1111/bph.13211.

82. Speiser J, Foreman K, Drinka E, Godellas C, Perez C, Salhadar A, et al. Notch-1 and Notch-4 biomarker expression in triple-negative breast cancer. Int J Surg Pathol. 2012;20(2):139-45. https://doi.org/10.1177/ 1066896911427035

83. Sardesai S, Badawi M, Mrozek E, Morgan E, Phelps M, Stephens J, et al. A phase I study of an oral selective gamma secretase (GS) inhibitor RO4929097 in combination with neoadjuvant paclitaxel and carboplatin in triple negative breast cancer. Invest New Drugs. 2020;38(5):1400-10. https://doi.org/10.1007/s10637-020-00895-5.

84. Kumari M, Krishnamurthy PT, Pinduprolu SKSS, Sola P. DR-5 and DLL-4 mAb Functionalized SLNs of Gamma-Secretase Inhibitors- An Approach for TNBC Treatment. Adv Pharm Bull. 2021;11(4):618-23. https://doi.org/ 10.34172/apb.2021.070

85. Previs RA, Coleman RL, Harris AL, Sood AK. Molecular pathways: translational and therapeutic implications of the Notch signaling pathway in cancer. Clin Cancer Res. 2015;21(5):955-61. https://doi.org/10.1158/ 1078-0432.Ccr-14-0809.

86. Majumder S, Crabtree JS, Golde TE, Minter LM, Osborne BA, Miele L. Targeting Notch in oncology: the path forward. Nat Rev Drug Discov. 2021;20(2):125-44. https://doi.org/10.1038/s41573-020-00091-3.

87. Stevens KN, Vachon CM, Couch FJ. Genetic susceptibility to triplenegative breast cancer. Cancer Res. 2013;73(7):2025-30. https://doi.org/ 10.1158/0008-5472.Can-12-1699.

88. Wu N, Zhang J, Zhao J, Mu K, Zhang J, Jin Z, et al. Precision medicine based on tumorigenic signaling pathways for triple-negative breast cancer. Oncol Lett. 2018;16(4):4984-96. https://doi.org/10.3892/ol.2018. 9290.

89. Pierce AJ, Stark JM, Araujo FD, Moynahan ME, Berwick M, Jasin M. Double-strand breaks and tumorigenesis. Trends Cell Biol. 2001;11(11):S529. https://doi.org/10.1016/s0962-8924(01)02149-3.

90. Bouwman P, Jonkers J. The effects of deregulated DNA damage signalling on cancer chemotherapy response and resistance. Nat Rev Cancer. 2012;12(9):587-98. https://doi.org/10.1038/nrc3342.

91. Gunn AR, Banos-Pinero B, Paschke P, Sanchez-Pulido L, Ariza A, Day J, et al. The role of ADP-ribosylation in regulating DNA interstrand crosslink repair. J Cell Sci. 2016;129(20):3845-58. https://doi.org/10.1242/jcs. 193375.

92. Zhu X, Chen L, Huang B, Li X, Yang L, Hu X, et al. Efficacy and mechanism of the combination of PARP and CDK4/6 inhibitors in the treatment of triple-negative breast cancer. J Exp Clin Cancer Res. 2021;40(1):122. https://doi.org/10.1186/s13046-021-01930-w.

93. Han Y, YU X, Li S, Tian Y, Liu C. New Perspectives for Resistance to PARP Inhibitors in Triple-Negative Breast Cancer. Front Oncol. 2020;10:578095. https://doi.org/10.3389/fonc.2020.578095.
94. Won KA, Spruck C. Triple-negative breast cancer therapy: Current and future perspectives (Review). Int J Oncol. 2020;57(6):1245-61. https:// doi.org/10.3892/ijo.2020.5135.

95. Olaparib for Metastatic Breast Cancer in Patients with a Germline BRCA Mutation. N Engl J Med.2017;377(17):1700 https://doi.org/10.1056/ NEJMX170012

96. Ettl J, Quek RGW, Lee KH, Rugo HS, Hurvitz S, Gonçalves A, et al. Quality of life with talazoparib versus physician's choice of chemotherapy in patients with advanced breast cancer and germline BRCA1/2 mutation: patient-reported outcomes from the EMBRACA phase III trial. Ann Oncol. 2018;29(9):1939-47. https://doi.org/10.1093/annonc/mdy257.

97. Gajan A, Sarma A, Kim S, Gurdziel K, Wu GS, Shekhar MP. Analysis of Adaptive Olaparib Resistance Effects on Cisplatin Sensitivity in Triple Negative Breast Cancer Cells. Front Oncol. 2021;11:694793. https://doi. org/10.3389/fonc.2021.694793.

98. Vinayak S, Tolaney SM, Schwartzberg L, Mita M, McCann G, Tan AR, et al. Open-label Clinical Trial of Niraparib Combined With Pembrolizumab for Treatment of Advanced or Metastatic Triple-Negative Breast Cancer. JAMA Oncol. 2019;5(8):1132-40. https://doi.org/10.1001/jamaoncol. 2019.1029.

99. Merikhian P, Eisavand MR, Farahmand L. Triple-negative breast cancer: understanding Wnt signaling in drug resistance. Cancer Cell Int. 2021;21(1):419. https://doi.org/10.1186/s12935-021-02107-3.

100. Xu X, Zhang M, Xu F, Jiang S. Wnt signaling in breast cancer: biological mechanisms, challenges and opportunities. Mol Cancer. 2020;19(1):165. https://doi.org/10.1186/s12943-020-01276-5.

101. Nusse R, Clevers H. Wnt/ $\beta$-Catenin Signaling, Disease, and Emerging Therapeutic Modalities. Cell. 2017;169(6):985-99. https://doi.org/10. 1016/j.cell.2017.05.016

102. Hart MJ, de los Santos R, Albert IN, Rubinfeld B, Polakis P. Downregulation of beta-catenin by human $A x i n$ and its association with the APC tumor suppressor, beta-catenin and GSK3 beta. Curr Biol. 1998;8(10):573-81. https://doi.org/10.1016/s0960-9822(98)70226-x.

103. Ikeda S, Kishida S, Yamamoto H, Murai H, Koyama S, Kikuchi A. Axin, a negative regulator of the Wnt signaling pathway, forms a complex with GSK-3beta and beta-catenin and promotes GSK-3beta-dependent phosphorylation of beta-catenin. Embo j. 1998;17(5):1371-84. https:// doi.org/10.1093/emboj/17.5.1371.

104. Liu C, Li Y, Semenov M, Han C, Baeg GH, Tan Y, et al. Control of betacatenin phosphorylation/degradation by a dual-kinase mechanism. Cell. 2002;108(6):837-47. https://doi.org/10.1016/s0092-8674(02) 00685-2.

105. Wong HC, Bourdelas A, Krauss A, Lee HJ, Shao Y, Wu D, et al. Direct binding of the PDZ domain of Dishevelled to a conserved internal sequence in the C-terminal region of Frizzled. Mol Cell. 2003;12(5):1251-60. https://doi.org/10.1016/s1097-2765(03)00427-1.

106. Lecarpentier Y, Schussler O, Hébert JL, Vallée A. Multiple Targets of the Canonical WNT/ß-Catenin Signaling in Cancers. Front Oncol. 2019:9:1248. https://doi.org/10.3389/fonc.2019.01248.

107. King TD, Suto MJ, Li Y. The Wnt/B-catenin signaling pathway: a potential therapeutic target in the treatment of triple negative breast cancer. J Cell Biochem. 2012;113(1):13-8. https://doi.org/10.1002/jcb.23350.

108. Tamai K, Semenov M, Kato Y, Spokony R, Liu C, Katsuyama Y, et al. LDL-receptor-related proteins in Wnt signal transduction. Nature. 2000;407(6803):530-5. https://doi.org/10.1038/35035117.

109. Dann CE, Hsieh JC, Rattner A, Sharma D, Nathans J, Leahy DJ. Insights into Wnt binding and signalling from the structures of two Frizzled cysteine-rich domains. Nature. 2001;412(6842):86-90. https://doi.org/ $10.1038 / 35083601$.

110. Hsieh JC, Kodjabachian L, Rebbert ML, Rattner A, Smallwood PM, Samos $\mathrm{CH}$, et al. A new secreted protein that binds to Wnt proteins and inhibits their activities. Nature. 1999;398(6726):431-6. https://doi.org/ 10.1038/18899.

111. de AbreuOliveira WA, Moens S, El Laithy Y, van der Veer BK, Athanasouli P, Cortesi EE, et al. Wnt/ $\beta$-Catenin Inhibition Disrupts Carboplatin Resistance in Isogenic Models of Triple-Negative Breast Cancer. Front Oncol. 2021;11:705384. https://doi.org/10.3389/fonc.2021.705384.

112. Chaudhury A, Howe PH. The tale of transforming growth factor-beta (TGFbeta) signaling: a soigné enigma. IUBMB Life. 2009;61(10):929-39. https://doi.org/10.1002/iub.239. 
113. Rahimi RA, Leof EB. TGF-beta signaling: a tale of two responses. J Cell Biochem. 2007;102(3):593-608. https://doi.org/10.1002/jcb.21501.

114. Sulaiman A, McGarry S, Chilumula SC, Kandunuri R, Vinod V. Clinically Translatable Approaches of Inhibiting TGF- $\beta$ to Target Cancer Stem Cells in TNBC. Biomedicines.2021;9(10) https://doi.org/10.3390/biome dicines9101386

115. Miyazono K, ten Dijke P, Heldin CH. TGF-beta signaling by Smad proteins. Adv Immunol. 2000;75:115-57. https://doi.org/10.1016/s00652776(00)75003-6.

116. Attisano L, Wrana JL. Signal transduction by the TGF-beta superfamily. Science. 2002;296(5573):1646-7. https://doi.org/10.1126/science.10718 09.

117. Vincent T, Neve EP, Johnson JR, Kukalev A, Rojo F, Albanell J, et al. A SNAIL1-SMAD3/4 transcriptional repressor complex promotes TGF-beta mediated epithelial-mesenchymal transition. Nat Cell Biol. 2009:11(8):943-50. https://doi.org/10.1038/ncb1905.

118. Valcourt U, Kowanetz M, Niimi H, Heldin CH, Moustakas A. TGF-beta and the Smad signaling pathway support transcriptomic reprogramming during epithelial-mesenchymal cell transition. Mol Biol Cell. 2005:16(4):1987-2002. https://doi.org/10.1091/mbc.e04-08-0658.

119. Kim S, Lee J, Jeon M, Lee JE, Nam SJ. Zerumbone suppresses the motility and tumorigenecity of triple negative breast cancer cells via the inhibition of TGF- $\beta 1$ signaling pathway. Oncotarget. 2016;7(2):1544-58. https://doi.org/10.18632/oncotarget.6441.

120. Kim S, Lee J, Jeon M, Nam SJ, Lee JE. Elevated TGF- $\beta 1$ and - $\beta 2$ expression accelerates the epithelial to mesenchymal transition in triple-negative breast cancer cells. Cytokine. 2015;75(1):151-8. https://doi.org/10. 1016/j.cyto.2015.05.020

121. Wahdan-Alaswad R, Harrell JC, Fan Z, Edgerton SM, Liu B, Thor AD. Metformin attenuates transforming growth factor beta (TGF- $\beta$ ) mediated oncogenesis in mesenchymal stem-like/claudin-low triple negative breast cancer. Cell Cycle. 2016;15(8):1046-59. https://doi.org/10.1080/ 15384101.2016.1152432

122. Liu B, Fan Z, Edgerton SM, Deng XS, Alimova IN, Lind SE, et al. Metformin induces unique biological and molecular responses in triple negative breast cancer cells. Cell Cycle. 2009;8(13):2031-40. https://doi. org/10.4161/cc.8.13.8814.

123. Bhola NE, Balko JM, Dugger TC, Kuba MG, Sánchez V, Sanders M, et al. TGF- $\beta$ inhibition enhances chemotherapy action against triple-negative breast cancer. J Clin Invest. 2013;123(3):1348-58. https://doi.org/10. 1172/jci65416.

124. Park S, Koo J, Park HS, Kim JH, Choi SY, Lee JH, et al. Expression of androgen receptors in primary breast cancer. Ann Oncol. 2010;21(3):488-92. https://doi.org/10.1093/annonc/mdp510.

125. Gucalp A, Traina TA. Triple-negative breast cancer: role of the androgen receptor. Cancer J. 2010;16(1):62-5. https://doi.org/10.1097/PPO.0b013 e3181ce4ae1.

126. Liao DJ, Dickson RB. Roles of androgens in the development, growth, and carcinogenesis of the mammary gland. J Steroid Biochem Mol Biol. 2002;80(2):175-89. https://doi.org/10.1016/s0960-0760(01)00185-6.

127. Gucalp A, Tolaney S, Isakoff SJ, Ingle JN, Liu MC, Carey LA, et al. Phase II trial of bicalutamide in patients with androgen receptor-positive, estrogen receptor-negative metastatic Breast Cancer. Clin Cancer Res. 2013;19(19):5505-12. https://doi.org/10.1158/1078-0432.Ccr-12-3327.

128. Traina TA, Miller K, Yardley DA, Eakle J, Schwartzberg LS, O'Shaughnessy J, et al. Enzalutamide for the Treatment of Androgen Receptor-Expressing Triple-Negative Breast Cancer. J Clin Oncol. 2018;36(9):884-90. https://doi.org/10.1200/jco.2016.71.3495.

129. Lehmann BD, Bauer JA, Schafer JM, Pendleton CS, Tang L, Johnson KC, et al. PIK3CA mutations in androgen receptor-positive triple negative breast cancer confer sensitivity to the combination of PI3K and androgen receptor inhibitors. Breast Cancer Res. 2014;16(4):406. https://doi. org/10.1186/s13058-014-0406-X.

130. Nagayama A, Vidula N, Ellisen L, Bardia A. Novel antibody-drug conjugates for triple negative breast cancer. Therapeutic advances in medical oncology. 2020;12:1758835920915980. https://doi.org/10.1177/17588 35920915980

131. Lin CW, Zheng T, Grande G, Nanna AR, Rader C, Lerner RA. A new immunochemical strategy for triple-negative breast cancer therapy. Sci Rep. 2021;11(1):14875. https://doi.org/10.1038/s41598-021-94230-4.
132. Medford A, Spring LM, Moy B, Bardia A. Antibody drug conjugates for patients with breast cancer. Curr Probl Cancer.2021;:100795 https://doi. org/10.1016/j.currproblcancer.2021.100795

133. Goldenberg DM, Sharkey RM. Sacituzumab govitecan, a novel, thirdgeneration, antibody-drug conjugate (ADC) for cancer therapy. Expert Opin Biol Ther. 2020;20(8):871-85. https://doi.org/10.1080/14712598. 2020.1757067.

134 Vidula N, Yau C, Rugo HS. Trop2 gene expression (Trop2e) in primary breast cancer (BC): Correlations with clinical and tumor characteristics. Journal of Clinical Oncology. 2017;35(15_suppl):1075-1075. https://doi. org/10.1200/JCO.2017.35.15_suppl.1075.

135. Bardia A, Mayer IA, Diamond JR, Moroose RL, Isakoff SJ, Starodub AN, et al. Efficacy and Safety of Anti-Trop-2 Antibody Drug Conjugate Sacituzumab Govitecan (IMMU-132) in Heavily Pretreated Patients With Metastatic Triple-Negative Breast Cancer. J Clin Oncol. 2017;35(19):2141-8. https://doi.org/10.1200/jco.2016.70.8297.

136. Bardia A, Tolaney SM, Loirat D, Punie K, Oliveira M, Rugo HS, et al. LBA17 ASCENT: A randomized phase III study of sacituzumab govitecan (SG) vs treatment of physician's choice (TPC) in patients (pts) with previously treated metastatic triple-negative breast cancer (mTNBC). Ann Oncol. 2020;31:S1149-50. https://doi.org/10.1016/j.annonc.2020.08.2245.

137. Waldman AD, Fritz JM, Lenardo MJ. A guide to cancer immunotherapy: from T cell basic science to clinical practice. Nat Rev Immunol. 2020;20(11):651-68. https://doi.org/10.1038/s41577-020-0306-5.

138. Telli ML, Stover DG, Loi S, Aparicio S, Carey LA, Domchek SM, et al. Homologous recombination deficiency and host anti-tumor immunity in triple-negative breast cancer. Breast Cancer Res Treat. 2018;171(1):21-31. https://doi.org/10.1007/s10549-018-4807-x.

139. Simmons CE, Brezden-Masley C, McCarthy J, McLeod D, Joy AA. Positive progress: current and evolving role of immune checkpoint inhibitors in metastatic triple-negative breast cancer. Ther Adv Med Oncol. 2020;12:1758835920909091. https://doi.org/10.1177/1758835920 909091.

140. Darvin P, Toor SM, Sasidharan Nair V, Elkord E. Immune checkpoint inhibitors: recent progress and potential biomarkers. Exp Mol Med. 2018;50(12):1-11. https://doi.org/10.1038/s12276-018-0191-1.

141 Reddy SM, Carroll E, Nanda R. Atezolizumab for the treatment of breast cancer. Expert review of anticancer. 2020;20(3):151-8. https://doi.org/ 10.1080/14737140.2020.1732211.

142. Cortes J, Cescon DW, Rugo HS, Nowecki Z, Im SA, Yusof MM, et al. Pembrolizumab plus chemotherapy versus placebo plus chemotherapy for previously untreated locally recurrent inoperable or metastatic triple-negative breast cancer (KEYNOTE-355): a randomised, placebo-controlled, double-blind, phase 3 clinical trial. Lancet. 2020;396(10265):1817-28. https://doi.org/10.1016/s0140-6736(20) 32531-9.

143. Heeke AL, Tan AR. Checkpoint inhibitor therapy for metastatic triplenegative breast cancer. Cancer Metastasis Rev. 2021;40(2):537-47. https://doi.org/10.1007/s10555-021-09972-4.

144. Cortesi L, Rugo HS, Jackisch C. An Overview of PARP Inhibitors for the Treatment of Breast Cancer. Target Oncol. 2021;16(3):255-82. https:// doi.org/10.1007/s11523-021-00796-4.

145 Bielenberg DR, Zetter BR. The Contribution of Angiogenesis to the Process of Metastasis. Cancer journal (Sudbury, Mass). 2015;21(4):267-73. https://doi.org/10.1097/PPO.0000000000000138.

146. Zimna A, Kurpisz M. Hypoxia-Inducible Factor-1 in Physiological and Pathophysiological Angiogenesis: Applications and Therapies. Biomed Res Int. 2015;2015:549412. https://doi.org/10.1155/2015/549412.

147. Ahmed F, Onwumeh-Okwundu J, Yukselen Z, Endaya Coronel M-K, Zaidi M, Guntipalli P, et al. Atezolizumab plus bevacizumab versus sorafenib or atezolizumab alone for unresectable hepatocellular carcinoma: A systematic review. World J Gastrointest Oncol. 2021:13(11):1813-32. https://doi.org/10.4251/wjgo.v13.i11.1813.

148. Kim S, You D, Jeong Y, Yu J, Kim SW, Nam SJ, et al. Berberine down-regulates IL-8 expression through inhibition of the EGFR/MEK/ERK pathway in triple-negative breast cancer cells. Phytomedicine. 2018;50:43-9. https://doi.org/10.1016/j.phymed.2018.08.004.

149. Acosta JC, O'Loghlen A, Banito A, Guijarro MV, Augert A, Raguz S, et al. Chemokine signaling via the CXCR2 receptor reinforces senescence. Cell. 2008;133(6):1006-18. https://doi.org/10.1016/j.cell.2008.03.038. 
150 Highfill SL, Cui Y, Giles AJ, Smith JP, Zhang H, Morse E, et al. Disruption of CXCR2-mediated MDSC tumor trafficking enhances anti-PD1 efficacy. Sci Transl Med. 2014;6(237):237ra67. https://doi.org/10.1126/scitranslm ed.3007974.

151. Bilusic M, Heery CR, Collins JM, Donahue RN, Palena C, Madan RA, et al. Phase I trial of HuMax-IL8 (BMS-986253), an anti-IL-8 monoclonal antibody, in patients with metastatic or unresectable solid tumors. J Immunother Cancer. 2019;7(1):240. https://doi.org/10.1186/ s40425-019-0706-x.

152. Deaglio S, Dwyer KM, Gao W, Friedman D, Usheva A, Erat A, et al. Adenosine generation catalyzed by CD39 and CD73 expressed on regulatory T cells mediates immune suppression. J Exp Med. 2007;204(6):1257-65.

153. Mediratta K, El-Sahli S, D'Costa V, Wang L. Current Progresses and Challenges of Immunotherapy in Triple-Negative Breast Cancer. Cancers.2020;12(12) https://doi.org/10.3390/cancers12123529

154. Miles D, Gligorov J, André F, Cameron D, Schneeweiss A, Barrios C, et al. Primary results from IMpassion131, a double-blind, placebo-controlled, randomised phase III trial of first-line paclitaxel with or without atezolizumab for unresectable locally advanced/metastatic triple-negative breast cancer. Annals of oncology : official journal of the European Society for Medical Oncology.2021;32(8) https://doi.org/10.1016/j.annonc. 2021.05.801

155 Mittendorf EA, Zhang H, Barrios CH, Saji S, Jung KH, Hegg R, et al. Neoadjuvant atezolizumab in combination with sequential nabpaclitaxel and anthracycline-based chemotherapy versus placebo and chemotherapy in patients with early-stage triple-negative breast cancer (IMpassion031): a randomised, double-blind, phase 3 trial. Lancet (London, England). 2020;396(10257):1090-100. https://doi.org/10.1016/ S0140-6736(20)31953-X

156 Schmid P, Cortes J, Pusztai L, McArthur H, Kümmel S, Bergh J, et al. Pembrolizumab for Early Triple-Negative Breast Cancer. The New England journal of medicine. 2020;382(9):810-21. https://doi.org/10.1056/ NEJMoa1910549.

157. Schmid P, Salgado R, Park YH, Muñoz-Couselo E, Kim SB, Sohn J, et al. Pembrolizumab plus chemotherapy as neoadjuvant treatment of high-risk, early-stage triple-negative breast cancer: results from the phase $1 \mathrm{~b}$ open-label, multicohort KEYNOTE-173 study. Annals of oncology : official journal of the European Society for Medical Oncology. 2020;31(5):569-81. https://doi.org/10.1016/j.annonc.2020.01.072.

158. Nanda R, Chow LQM, Dees EC, Berger R, Gupta S, Geva R, et al. Pembrolizumab in Patients With Advanced Triple-Negative Breast Cancer: Phase Ib KEYNOTE-012 Study. Journal of clinical oncology : official journal of the American Society of Clinical Oncology. 2016;34(21):2460-7. https://doi.org/10.1200/JCO.2015.64.8931.

159. Emens LA, Cruz C, Eder JP, Braiteh F, Chung C, Tolaney SM, et al. Longterm Clinical Outcomes and Biomarker Analyses of Atezolizumab Therapy for Patients With Metastatic Triple-Negative Breast Cancer: A Phase 1 Study. JAMA oncology. 2019;5(1):74-82. https://doi.org/10. 1001/jamaoncol.2018.4224.

160. Bian L, Zhang H, Wang T, Zhang S, Song H, Xu M, et al. JSO01, an anti-PD-1 mAb for advanced triple negative breast cancer patients after multi-line systemic therapy in a phase I trial. Ann TransI Med. 2019;7(18):435. https://doi.org/10.21037/atm.2019.09.08.

161. Adams S, Schmid P, Rugo HS, Winer EP, Loirat D, Awada A, et al. Pembrolizumab monotherapy for previously treated metastatic triple-negative breast cancer: cohort A of the phase II KEYNOTE-086 study. Annals of oncology : official journal of the European Society for Medical Oncology. 2019;30(3):397-404. https://doi.org/10.1093/annonc/mdy517.

162. Adams S, Loi S, Toppmeyer D, Cescon DW, De Laurentiis M, Nanda $R$, et al. Pembrolizumab monotherapy for previously untreated, PDL1-positive, metastatic triple-negative breast cancer: cohort B of the phase II KEYNOTE-086 study. Annals of oncology : official journal of the European Society for Medical Oncology. 2019;30(3):405-11. https://doi. org/10.1093/annonc/mdy518.

163. Voorwerk L, Slagter M, Horlings HM, Sikorska K, van de Vijver KK, de Maaker $\mathrm{M}$, et al. Immune induction strategies in metastatic triplenegative breast cancer to enhance the sensitivity to PD-1 blockade: the TONIC trial. Nat Med. 2019;25(6):920-8. https://doi.org/10.1038/ s41591-019-0432-4

164. Winer EP, Lipatov O, Im S-A, Goncalves A, Muñoz-Couselo E, Lee KS, et al. Pembrolizumab versus investigator-choice chemotherapy for metastatic triple-negative breast cancer (KEYNOTE-119): a randomised, open-label, phase 3 trial. Lancet Oncol. 2021;22(4):499-511. https://doi, org/10.1016/S1470-2045(20)30754-3.

\section{Publisher's Note}

Springer Nature remains neutral with regard to jurisdictional claims in published maps and institutional affiliations. 